\title{
Cyclooctanoid Ring Systems from Mixed Acetals via Heteroatom-Assisted [1,2]-Shift of Oxonium Ylides
}

\author{
Fredrik P. Marmsäter, Graham K. Murphy and F. G. West* \\ Department of Chemistry, University of Alberta, Edmonton, Alta., Canada T6G 2 G2.
}

\section{Supporting Information}

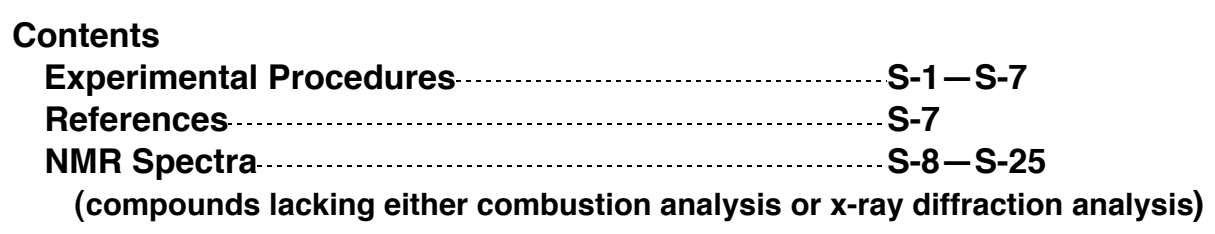

(X-ray data for compounds $7 \mathrm{~b}$ and 11 are found in a separate .cif file.)

\section{Experimental Procedures}

General. Reactions were carried out in flame-dried glassware under a positive nitrogen atmosphere unless otherwise stated. Transfer of anhydrous solvents and reagents was accomplished with oven-dried syringes or cannula. Solvents were distilled before use: methylene chloride from calcium hydride, tetrahydrofuran and diethylether from sodium/benzophenone ketyl, toluene from sodium metal. Ethereal diazomethane (hazard!) ${ }^{1}$ was prepared from Diazald according to literature procedures. ${ }^{1}$ Thin layer chromatography was performed on glass plates precoated with $0.25 \mathrm{~mm}$ Kieselgel $60 \mathrm{~F}_{254}$ (Merck). Flash chromatography columns were packed with 230-400 mesh silica gel (Merck). Radial chromatography was carried out on a Chromatotron 7924T (Harrison Research) with plates prepared using silica gel $60 \mathrm{~F}_{254}$ with gypsum binder $(\mathrm{EM})$ on glass rotors. Proton nuclear magnetic resonance spectra ( ${ }^{1} \mathrm{H}$ NMR) were recorded at $300 \mathrm{MHz}, 400 \mathrm{MHz}$ or $500 \mathrm{MHz}$ and coupling constants $(J)$ are reported in Hertz $(\mathrm{Hz})$. Carbon nuclear magnetic resonance spectra $\left({ }^{13} \mathrm{C}\right.$ NMR) were recorded at $75 \mathrm{MHz}, 100 \mathrm{MHz}$ or $125 \mathrm{MHz}$ and are reported (ppm) relative to the center line of the triplet from chloroform- $d(77.23 \mathrm{ppm})$.

Ethyl 2-(2-(3,3-Dimethoxypropyl)-1-hydroxycyclopent-1-yl)acetate. To a two neck flask equipped with a large stir bar and condenser, charged with a mixture of $\mathrm{Zn}$ (400 mg, $6.1 \mathrm{mmol}$ ) in $\mathrm{Et}_{2} \mathrm{O}(6 \mathrm{~mL})$, was added via syringe $\mathrm{TMSCl}(47 \mu \mathrm{L}, 0.36 \mathrm{mmol}){ }^{2}$ The mixture was then heated to reflux for $15 \mathrm{~min}$ then stirred at r.t. for an additional $15 \mathrm{~min}$. Freshly distilled ethyl bromoacetate $(0.68 \mathrm{~mL}, 6.1 \mathrm{mmol})$ was added dropwise via syringe. The mixture was heated to reflux for $45 \mathrm{~min}$ and then stirred at r.t. for an additional $1 \mathrm{~h}$. During this time, the mixture turned to a yellow tint and most of the solid $\mathrm{Zn}$ was consumed. The solution of Reformatsky reagent thus prepared was then transferred via cannula to a second flask, leaving behind any remaining solid $\mathrm{Zn}$. The flask was then cooled to $-10^{\circ} \mathrm{C}$ (acetone/ice bath) and 2-((3,3)methoxypropyl)-cyclopentanone ${ }^{3}(677 \mathrm{mg}, 3.61 \mathrm{mmol})$ was slowly added as a solution in $\mathrm{Et}_{2} \mathrm{O}$ $(3 \mathrm{~mL})$ via cannula. The reaction was stirred at $-10^{\circ} \mathrm{C}$ for $1 \mathrm{~h}$ and then an additional $2 \mathrm{~h}$ at r.t. at which time the reaction had consumed the starting material as ascertained by TLC. The reaction was diluted with $\mathrm{Et}_{2} \mathrm{O}(30 \mathrm{~mL})$ and quenched by addition of sat. $\mathrm{NH}_{4} \mathrm{Cl}$ solution $(30 \mathrm{~mL})$. The aqueous phase was extracted with $\mathrm{Et}_{2} \mathrm{O}(3 \times 30 \mathrm{~mL})$, the combined organic phase was dried with 
$\mathrm{MgSO}_{4}$, filtered and concentrated. The resulting oil was purified by flash chromatography (silica gel, $3 \mathrm{~cm} \times 24 \mathrm{~cm}$ column, solvent ramp: $200 \mathrm{~mL}$ each of $20 \%, 30 \%, 40 \%$ EtOAc/hexanes) to yield the desired alcohol (856 mg, 87\%) as a 3.2:1 cis/trans mixture of diastereomers. $\mathrm{R}_{f} 0.17$ (30\% EtOAc/hexanes); IR ( $\mathrm{CH}_{2} \mathrm{Cl}_{2}$ cast) 3516, 2951, 2872, 1731, 1189, $1053 \mathrm{~cm}^{-1}$; ${ }^{1} \mathrm{H}$ NMR $\left(500 \mathrm{MHz}, \mathrm{CDCl}_{3}\right.$, major diastereomer) $\square 4.35(\mathrm{t}, J=5.7 \mathrm{~Hz}, 1 \mathrm{H}), 4.17(\mathrm{q}, J=7.2 \mathrm{~Hz}, 2 \mathrm{H}), 3,32$ $(\mathrm{s}, 3 \mathrm{H}), 3.30(\mathrm{~s}, 3 \mathrm{H}), 2.71\left(\mathrm{~d}, J_{\mathrm{AB}}=15.7 \mathrm{~Hz}, 1 \mathrm{H}\right), 2.33\left(\mathrm{~d}, J_{\mathrm{AB}}=15.4 \mathrm{~Hz}, 1 \mathrm{H}\right), 1.90-1.44(\mathrm{~m}$, $11 \mathrm{H}), 1.38-1.31(\mathrm{~m}, 1 \mathrm{H}), 1.28(\mathrm{t}, J=7.2 \mathrm{~Hz}, 3 \mathrm{H}) ;{ }^{13} \mathrm{C} \mathrm{NMR}\left(125 \mathrm{MHz}, \mathrm{CDCl}_{3}\right.$, major diastereomer) $\square 173.6,105.1,79.7,60.9,53.3,52.7,49.5,40.0,31.9,29.9,23.9,21.3,14.4$; HRMS (ES, M-32 (MeOH)) for $\mathrm{C}_{13} \mathrm{H}_{22} \mathrm{O}_{4}$ calcd 242.1518, found: $\mathrm{m} / \mathrm{z} 242.1521$.

Mixed Acetal 2a. To a solution of ethyl 2-(2-(3,3-dimethoxypropyl)-1-hydroxycyclopent-1yl)acetate (812 mg, $2.96 \mathrm{mmol}, 3.2: 1$ mixture of diastereomers) in $\mathrm{CH}_{2} \mathrm{Cl}_{2}$ (150 mL) cooled to $10^{\circ} \mathrm{C}$ (acetone/ice bath) was added via syringe $\mathrm{BF}_{3} \cdot \mathrm{OEt}_{2}(376 \mu \mathrm{L}, 2.96 \mathrm{mmol})$. The reaction was stirred for $15 \mathrm{~min}$ at which time the reaction had consumed the starting material as ascertained by TLC. The reaction was quenched by addition of $\mathrm{Et}_{3} \mathrm{~N}(\sim 1 \mathrm{~mL})$ followed by $\mathrm{H}_{2} \mathrm{O}(50 \mathrm{~mL})$. The aqueous phase was extracted with $\mathrm{CH}_{2} \mathrm{Cl}_{2}(50 \mathrm{~mL})$, the combined organic phase was washed with brine $(200 \mathrm{~mL})$, dried with $\mathrm{Na}_{2} \mathrm{SO}_{4}$, filtered and concentrated. The resulting oil was purified by flash chromatography (silica gel, $3 \mathrm{~cm}$ x $24 \mathrm{~cm}$ column, solvent ramp: $200 \mathrm{~mL}$ each of $2.5 \%$, $5 \%, 10 \%, 20 \%$ EtOAc/hexanes) to yield the minor $(\square)$ anomer of $\mathbf{2 a}$ (99 $\mathrm{mg}, 18 \%$ based on 3.2:1 diastereomer ratio of starting material), major ( $\square$ ) anomer of $\mathbf{2 a}$ (354 $\mathrm{mg}, 65 \%$ based on 3.2:1 diastereomer ratio of starting material), and a mixture of anomers derived from the minor trans diastereomer (131 mg, 77\% based on 1:3.2 diastereomer ratio of starting material). Major anomer of 2a: $\mathrm{R}_{f} 0.49$ (30\% EtOAc/hexanes); IR (neat) 2953, 2870, 1734, 1368, 1225, 1150, $1016 \mathrm{~cm}^{-1} ;{ }^{1} \mathrm{H} \mathrm{NMR}\left(500 \mathrm{MHz}, \mathrm{CDCl}_{3}\right.$, major anomer) $\square 4.62(\mathrm{dd}, J=8.8,3.2 \mathrm{~Hz}, 1 \mathrm{H}), 4.21$ (dq, $J=10.8,7.2 \mathrm{~Hz}, 1 \mathrm{H}), 4.09(\mathrm{dq}, J=10.8,7.2 \mathrm{~Hz}, 1 \mathrm{H}), 3.42(\mathrm{~s}, 3 \mathrm{H}) 2.97\left(\mathrm{~d}, J_{\mathrm{AB}}=13.4 \mathrm{~Hz}, 1 \mathrm{H}\right)$, $2.31\left(\mathrm{~d}, J_{\mathrm{AB}}=13.3 \mathrm{~Hz}, 1 \mathrm{H}\right), 2.10-2.05(\mathrm{~m}, 1 \mathrm{H}), 1.92-1.84(\mathrm{~m}, 2 \mathrm{H}), 1.82-1.65(\mathrm{~m}, 5 \mathrm{H}), 1.63-1.54$ $(\mathrm{m}, 3 \mathrm{H}) 1.27(\mathrm{t}, J=7.2 \mathrm{~Hz}, 3 \mathrm{H}) ;{ }^{13} \mathrm{C} \mathrm{NMR}\left(125 \mathrm{MHz}, \mathrm{CDCl}_{3}\right.$, major anomer) $\square$ 171.1, 98.6, 83.8, 60.5, 56.1, 41.1, 40.9, 39.9, 27.9, 25.9, 21.9, 21.8, 14.5; HRMS (ES) for $\mathrm{C}_{13} \mathrm{H}_{22} \mathrm{O}_{4}$ calcd 242.1518, found: $\mathrm{m} / \mathrm{z} 242.1516$.

Thioglycoside $\mathbf{2 b}$. A solution of $\mathbf{2 a}(275 \mathrm{mg}, 1.14 \mathrm{mmol})$ and thiocresol (141 $\mathrm{mg}, 1.14 \mathrm{mmol})$ in $\mathrm{CH}_{2} \mathrm{Cl}_{2}(114 \mathrm{~mL})$ was stirred for $10 \mathrm{~min}$ to ensure that the thiocresol was completely dissolved. The solution was cooled to $-10^{\circ} \mathrm{C}$ (acetone/ice bath) and $\mathrm{BF}_{3} \cdot \mathrm{OEt}_{2}(144 \mu \mathrm{L}, 1.14 \mathrm{mmol}$ ) was added dropwise via syringe. The reaction was stirred for $10 \mathrm{~min}$ at which time the reaction had consumed the starting material as ascertained by TLC. The reaction was quenched by addition of $\mathrm{Et}_{3} \mathrm{~N}(\sim 1 \mathrm{~mL})$ followed by $\mathrm{H}_{2} \mathrm{O}(50 \mathrm{~mL})$. The aqueous phase was extracted with $\mathrm{CH}_{2} \mathrm{Cl}_{2}(50$ $\mathrm{mL})$, the combined organic phase was washed with brine $(200 \mathrm{~mL})$, dried with $\mathrm{Na}_{2} \mathrm{SO}_{4}$, filtered and concentrated. The resulting oil was purified by radial chromatography ( $4 \mathrm{~mm}$ plate, solvent ramp: $100 \mathrm{~mL}$ each of $2.5 \%, 5 \%, 10 \%$, EtOAc/hexanes) to yield $\mathbf{2 b}$ as a single anomer (313 $\mathrm{mg}$, 82\%): $\mathrm{R}_{f} 0.53$ (30\% EtOAc/hexanes); IR $\left(\mathrm{CH}_{2} \mathrm{Cl}_{2}\right.$ cast) $2951,2869,1733,1221,1044 \mathrm{~cm}^{-1} ;{ }^{1} \mathrm{H}$ NMR (500 MHz, $\left.\mathrm{CDCl}_{3}\right) \square 7.41(\mathrm{~d}, J=8.3 \mathrm{~Hz}, 2 \mathrm{H}), 7.08(\mathrm{~d}, J=7.8 \mathrm{~Hz}, 2 \mathrm{H}), 4.90$ (dd, $J=10.6$, $3.6 \mathrm{~Hz}, 1 \mathrm{H}), 4.05(\mathrm{dq}, J=11.1,7.3 \mathrm{~Hz}, 1 \mathrm{H}), 3.95(\mathrm{dq}, J=10.9,7.3 \mathrm{~Hz}, 1 \mathrm{H}), 2.88\left(\mathrm{~d}, J_{\mathrm{AB}}=13.6\right.$ $\mathrm{Hz}, 1 \mathrm{H}), 2.45\left(\mathrm{~d}, J_{\mathrm{AB}}=13.5 \mathrm{~Hz}, 1 \mathrm{H}\right), 2.31(\mathrm{~s}, 3 \mathrm{H}), 2.10-2.05(\mathrm{~m}, 1 \mathrm{H}), 1.92-1.55(\mathrm{~m}, 10 \mathrm{H}), 1.19$ $(\mathrm{t}, J=7.1 \mathrm{~Hz}, 3 \mathrm{H}) ;{ }^{13} \mathrm{C} \mathrm{NMR}\left(125 \mathrm{MHz}, \mathrm{CDCl}_{3}\right) \square 170.9,137.6,133.4,130.1,129.5,84.6,79.8$, $60.5,40.1,39.9,39.4,27.7,25.9,22.7,22.0,21.3,14.4$; HRMS (ES, M-123 $\left(\mathrm{CH}_{3} \mathrm{C}_{6} \mathrm{H}_{4} \mathrm{~S}\right)$ ) for $\mathrm{C}_{12} \mathrm{H}_{19} \mathrm{O}_{3}$ calcd 211.1334, found: $\mathrm{m} / \mathrm{z} 211.1336$. 
$\left(1 S^{*}, 3 S^{*}, 6 R^{*}\right)-3-(4$ '-Methylphenyl)thio-2-oxabicycl[4.3.0] nonane-1-acetic acid. To a solution of $\mathbf{2 b}(850 \mathrm{mg}, 2.54 \mathrm{mmol})$ in THF $(2 \mathrm{~mL})$ and $\mathrm{MeOH}(4 \mathrm{~mL})$ was added a $2 \mathrm{~N}$ solution of $\mathrm{LiOH}(2.54 \mathrm{~mL})$. The reaction was stirred for about $12 \mathrm{~h}$ during which time the reaction turned slightly yellow and the starting material was consumed as ascertained by TLC. The reaction was diluted by addition of $\mathrm{Et}_{2} \mathrm{O}(50 \mathrm{~mL})$ and $\mathrm{H}_{2} \mathrm{O}(50 \mathrm{~mL})$. The aqueous phase was washed with $\mathrm{Et}_{2} \mathrm{O}(50 \mathrm{~mL})$. After the layers were separated, EtOAc $(50 \mathrm{~mL})$ was added to the aqueous phase followed by the dropwise addition of $3 \mathrm{~N} \mathrm{HCl}$ until the $\mathrm{pH}$ reached $\sim 2$. The cloudy aqueous phase was then extracted with EtOAc $(3 \times 30 \mathrm{~mL})$, the combined organic phase was dried with $\mathrm{Na}_{2} \mathrm{SO}_{4}$, filtered and concentrated to yield the desired acid as a white solid (743

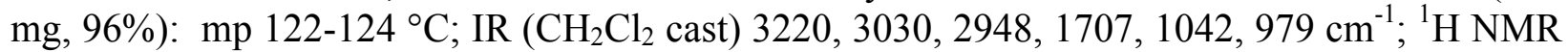
$\left(500 \mathrm{MHz}, \mathrm{CDCl}_{3}\right) \square 10.88$ (br s, 1H), 7.42 (d, $\left.J=8.1 \mathrm{~Hz}, 2 \mathrm{H}\right), 7.09$ (d, $\left.J=8.3 \mathrm{~Hz}, 2 \mathrm{H}\right), 4.89$ $4.86(\mathrm{~m}, 1 \mathrm{H}), 2.98\left(\mathrm{~d}, J_{\mathrm{AB}}=14.6 \mathrm{~Hz}, 1 \mathrm{H}\right), 2.39(\mathrm{dd}, J=14.5,1.9 \mathrm{~Hz}, 1 \mathrm{H}), 2.32(\mathrm{~s}, 3 \mathrm{H}), 2.13-2.08$ $(\mathrm{m}, 1 \mathrm{H}), 1.91-1.59(\mathrm{~m}, 10 \mathrm{H}) ;{ }^{13} \mathrm{C} \mathrm{NMR}\left(125 \mathrm{MHz}, \mathrm{CDCl}_{3}\right) \square$ 175.7, 138.1, 133.6, 129.6, 129.4, 84.6, 80.3, 40.4, 39.8, 38.9, 27.7, 25.8, 22.7, 21.9, 21.4; HRMS (ES) for $\mathrm{C}_{17} \mathrm{H}_{22} \mathrm{O}_{3} \mathrm{~S}$ calcd 306.1289, found: $\mathrm{m} / \mathrm{z} 306.1284$.

Diazoketone 4 b. To a solution of oxalyl chloride $(38 \mu \mathrm{L}, 0.44 \mathrm{mmol})$ and the acid in $\mathrm{CH}_{2} \mathrm{Cl}_{2}$ $(2.4 \mathrm{~mL})$ cooled to $-45^{\circ} \mathrm{C}$ (acetonitrile/dry ice bath) was added 1 drop of DMF. The reaction was stirred at this temperature for $1 \mathrm{~h}$ then allowed to warm to $-10^{\circ} \mathrm{C}$ (acetone/ice bath; gas evolution was observed during the warming of the reaction) and stirred an additional $1 \mathrm{~h}$ at that temperature. The reaction was then directly transferred via cannula to a freshly prepared solution of diazomethane $(\sim 4 \mathrm{mmol})$ in $\mathrm{Et}_{2} \mathrm{O}(\sim 12 \mathrm{~mL})$, cooled to $-45^{\circ} \mathrm{C}$ (acetonitrile/dry ice bath). The bath was allowed to expire, and a stream of $\mathrm{N}_{2}$ was introduced once the reaction reached r.t. The crude yellow oil thus obtained was passed through a short pad of silica gel (1 $\mathrm{cm}$ in a disposable pipette) eluting with $10 \mathrm{~mL}$ of $50 \%$ EtOAc/hexanes. The solvents were removed under reduced pressure and the resulting yellow oil was purified by radial chromatography ( $2 \mathrm{~mm}$ plate, solvent ramp: $100 \mathrm{~mL}$ each of 10\%, 20\%, 30\%, EtOAc/hexanes) to yield $4 \mathbf{b}$ as a yellow solid (88 $\mathrm{mg}, 73 \%)$. mp 93-94 ${ }^{\circ} \mathrm{C} ; \mathrm{R}_{f} 0.30$ (30\% EtOAc/hexanes); IR $\left(\mathrm{CH}_{2} \mathrm{Cl}_{2}\right.$ cast $) 2949,2868,2100,1635,1363,1044 \mathrm{~cm}^{-1} ;{ }^{1} \mathrm{H}$ NMR $\left(400 \mathrm{MHz}, \mathrm{CDCl}_{3}\right) \square 7.48(\mathrm{~d}$, $J=8.1 \mathrm{~Hz}, 2 \mathrm{H}), 7.12(\mathrm{~d}, J=8.2 \mathrm{~Hz}, 2 \mathrm{H}), 4.84-4.81(\mathrm{~m}, 1 \mathrm{H}), 4.78($ br s, $1 \mathrm{H}), 2.97\left(\mathrm{~d}, J_{\mathrm{AB}}=14.6\right.$ $\mathrm{Hz}, 1 \mathrm{H}), 2.31(\mathrm{~s}, 3 \mathrm{H}), 2.09$ (br app d, $\left.J_{\mathrm{AB}}=14.6 \mathrm{~Hz}, 1 \mathrm{H}\right), 1.95-1.54(\mathrm{~m}, 11 \mathrm{H}) ;{ }^{13} \mathrm{C}$ NMR $(100$ $\left.\mathrm{MHz}_{1} \mathrm{CDCl}_{3}\right) \square 193.0,138.7,135.1,129.7,129.5,84.6,80.6,55.2,45.7,42.0,39.0,27.8,25.8$, 22.8, 21.9, 21.3; HRMS (ES, M+Na) for $\mathrm{C}_{18} \mathrm{H}_{22} \mathrm{~N}_{2} \mathrm{O}_{2} \mathrm{NaS}$ calcd 353.1300, found: $\mathrm{m} / \mathrm{z} 353.1295$.

Catalytic Decomposition of Diazoketone $4 \mathrm{~b}$ with $\mathrm{Cu}$ (hfacac)2. 8-(p-Tolylthio)-12oxatricyclo[7.2.1.0 ${ }^{1,5}$ ]undecan-10-one $7 \mathbf{b}$. To a solution of $\mathrm{Cu}$ (hfacac) $)_{2}(11 \mathrm{mg}, 0.017 \mathrm{mmol}$, $10 \mathrm{~mol} \%)$ in $\mathrm{CH}_{2} \mathrm{Cl}_{2}(22 \mathrm{~mL}, 0.01 \mathrm{M})$ heated to reflux was added dropwise via cannula a solution of diazoketone $4 \mathbf{b}(56 \mathrm{mg}, 0.17 \mathrm{mmol})$ in $2 \mathrm{~mL}$ of $\mathrm{CH}_{2} \mathrm{Cl}_{2}$. Following completion of addition, the reaction was stirred at reflux until complete consumption (ca. $30 \mathrm{~min}$ ) of $\mathbf{4 b}$ (TLC monitoring), after which the reaction was cooled to r.t. and a solution of $0.5 \mathrm{M} \mathrm{K}_{2} \mathrm{CO}_{3}$ was added. The aqueous phase was then extracted with $\mathrm{CH}_{2} \mathrm{Cl}_{2}(2 \times 15 \mathrm{~mL})$ and the combined organic phase was dried with $\mathrm{MgSO}_{4}$, filtered, condensed, and purified by radial chromatography to yield $41 \mathrm{mg}(80 \%)$ of $\mathbf{7 b}$ as a white crystalline solid: $\mathrm{mp} 75-76{ }^{\circ} \mathrm{C} ; \mathrm{R}_{f} 0.53(30 \%$ EtOAc/hexanes); IR ( $\mathrm{CH}_{2} \mathrm{Cl}_{2}$ cast) 2934, 2866, 1753, 1492, 1081, $809 \mathrm{~cm}^{-1} ;{ }^{1} \mathrm{H}$ NMR (500 MHz, $\left.\mathrm{CDCl}_{3}\right) \square 7.35(\mathrm{~d}, J=8.2 \mathrm{~Hz}, 2 \mathrm{H}), 7.11(\mathrm{~d}, J=8.2 \mathrm{~Hz}, 2 \mathrm{H}), 4.27$ (app br s, 1H), 3.59 (ddd, $J=$ 
6.6, 4.7, 1.4 Hz, 1H), $2.74(\mathrm{dd}, J=17.5,1.1 \mathrm{~Hz}, 1 \mathrm{H}), 2.38(\mathrm{dd}, J=17.3,1.1 \mathrm{~Hz}, 1 \mathrm{H}), 2.31$ (s, $3 \mathrm{H}), 2.15-2.10(\mathrm{~m}, 1 \mathrm{H}), 2.02-1.96(\mathrm{~m}, 2 \mathrm{H}), 1.92-1.83(\mathrm{~m}, 2 \mathrm{H}), 1.80-1.64(\mathrm{~m}, 4 \mathrm{H}), 1.60-1.53(\mathrm{~m}$, 1H), 1.49-1.43 (m, 1H); ${ }^{13} \mathrm{C}$ NMR (125 MHz, $\left.\mathrm{CDCl}_{3}\right) \square 216.7,137.6,132.5,130.1,130.0,91.1$, 83.5, 51.7, 51.2, 49.1, 40.3, 32.1, 27.5, 26.3, 23.4, 21.3; HRMS (EI) for $\mathrm{C}_{18} \mathrm{H}_{22} \mathrm{O}_{2} \mathrm{~S}$ calcd 302.1341, found: $\mathrm{m} / \mathrm{z} 302.1342$.

Ketal 9. A flask containing a solution of $7 \mathbf{b}(67 \mathrm{mg}, 0.22 \mathrm{mmol})$, ethylene glycol $(144 \mu \mathrm{L}, 3.32$ $\mathrm{mmol})$, TsOH (2 mg, $0.01 \mathrm{mmol})$ in toluene $(5 \mathrm{~mL})$ was equipped with a condenser and DeanStark trap (pre-filled with toluene), and then heated to reflux for $12 \mathrm{~h}$. The reaction was cooled to r.t. and the solution was transferred to a separatory funnel and washed with sat. $\mathrm{NaHCO}_{3}(10$ $\mathrm{mL}$ ). The organic phase was dried with $\mathrm{MgSO}_{4}$, filtered and the solvent was removed under reduced pressure. The crude white solid thus obtained was passed through a short pad of silica gel ( $1 \mathrm{~cm}$ in a disposable pipette) eluting with $10 \mathrm{~mL}$ of $30 \%$ EtOAc/hexanes. The solvents were removed under reduced pressure and the resulting white solid was purified by radial chromatography (2 $\mathrm{mm}$ plate, solvent ramp: $100 \mathrm{~mL}$ of hexanes, $2.5 \%, 5 \%, 10 \%$, EtOAc/hexanes) to yield recovered $7 \mathbf{b}(16 \mathrm{mg}, 25 \%)$ and $9(55 \mathrm{mg}, 73 \%)$ as a white solid: $\mathrm{R}_{f}$ 0.18 (5\% EtOAc/hexanes); IR ( $\mathrm{CH}_{2} \mathrm{Cl}_{2}$ cast) 2946, 2868, 1319, $1092 \mathrm{~cm}^{-1}$; ${ }^{1} \mathrm{H} \mathrm{NMR}$ (500 MHz, $\left.\mathrm{CDCl}_{3}\right) \square 7.35(\mathrm{~d}, J=8.1 \mathrm{~Hz}, 2 \mathrm{H}), 7.09(\mathrm{~d}, J=7.9 \mathrm{~Hz}, 2 \mathrm{H}), 4.11$ (app br s, 1H), 3.93 (ddd, $J=$ 8.0, 6.6, $4.9 \mathrm{~Hz}, 1 \mathrm{H}), 3.85$ (app q $J=7.3 \mathrm{~Hz}, 1 \mathrm{H}), 3.77$ (ddd, $J=6.9,6.9,4.9 \mathrm{~Hz}, 1 \mathrm{H}), 3.62$ (ddd, $J=7.9,7.1,7.1 \mathrm{~Hz}, 1 \mathrm{H}), 3.62-3.48(\mathrm{~m}, 1 \mathrm{H}), 2.35\left(\mathrm{~d}, J_{A B}=14.2 \mathrm{~Hz}, 1 \mathrm{H}\right), 2.32(\mathrm{~s}, 3 \mathrm{H}) 2.27(\mathrm{~d}$, $\left.J_{\mathrm{AB}}=14.2 \mathrm{~Hz}, 1 \mathrm{H}\right), 2.05-1.99(\mathrm{~m}, 1 \mathrm{H}), 1.96-1.89(\mathrm{~m}, 3 \mathrm{H}), 1.83-1.70(\mathrm{~m}, 4 \mathrm{H}), 1.65-1.47(\mathrm{~m}, 3 \mathrm{H})$; ${ }^{13} \mathrm{C}$ NMR $\left(125 \mathrm{MHz}, \mathrm{CDCl}_{3}\right) \square 137.3,132.9,132.1,129.9,117.1,92.0,86.5,65.4,64.2,50.9$, 50.8, 48.0, 41.9, 32.4, 27.8, 26.6, 23.5, 21.3; HRMS (EI) for $\mathrm{C}_{20} \mathrm{H}_{26} \mathrm{O}_{3} \mathrm{~S}$ calcd 346.1603, found: $\mathrm{m} / \mathrm{z} 346.1600$.

Cyclooctenone Ketal 10. This procedure was carried out under an argon atmosphere. A large excess of LiDBB solution was prepared according to Cohen's procedure [Li $(10 \mathrm{mg})$, di-tertbutylbiphenyl (DBB) $(358 \mathrm{mg})$, THF $(4.5 \mathrm{~mL})]^{4}$ To a solution of $9(14 \mathrm{mg}, 0.04 \mathrm{mmol})$ and a crystal of phenanthroline in THF $(0.17 \mathrm{~mL})$ cooled to $-78^{\circ} \mathrm{C}$ (isopropanol/dry ice bath) $n \mathrm{BuLi}$ $\left(\sim 10 \mu \mathrm{L}, 2.52 \mathrm{M}\right.$ in hexanes) was added dropwise until the solution turned a red color. ${ }^{5}$ LiDBB was then added dropwise via cannula to this solution until a persistent dark green color was observed, indicating an excess of LiDBB (exact volume of LiDBB added not measured). Starting material was consumed within $30 \mathrm{~min}$ (TLC). The reaction was allowed to stir for an additional $1 \mathrm{~h}$ at $-78^{\circ} \mathrm{C}$, the cooling bath was then removed followed by the immediate addition of sat. $\mathrm{NH}_{4} \mathrm{Cl}$ solution $(5 \mathrm{~mL})$ and $\mathrm{Et}_{2} \mathrm{O}(5 \mathrm{~mL})$. The mixture was then transferred to a separatory funnel, the aqueous phase was back extracted with $\mathrm{Et}_{2} \mathrm{O}(5 \mathrm{~mL})$, the combined organic phase was washed with brine $(10 \mathrm{~mL})$ and dried with $\mathrm{MgSO}_{4}$, filtered and the solvents were removed under reduced pressure. The resulting crude material was purified by radial chromatography $(2 \mathrm{~mm}$ plate, solvent ramp: $100 \mathrm{~mL}$ each of hexanes, 5\%, 15\%, 30\% EtOAc/hexanes) to yield $\mathbf{1 0}(9 \mathrm{mg}, 97 \%)$ as a colorless oil: $\mathrm{R}_{f} 0.32$ (30\% EtOAc/hexanes); IR $\left(\mathrm{CH}_{2} \mathrm{Cl}_{2}\right.$ cast $) 3542,3018,2948,1061,757 \mathrm{~cm}^{-1} ;{ }^{1} \mathrm{H}$ NMR $\left(500 \mathrm{MHz}, \mathrm{CDCl}_{3}\right) \square 5.78(\mathrm{ddd}, J=$ $11.5,9.7,7.6 \mathrm{~Hz}, 1 \mathrm{H}) 5.58(\mathrm{dd}, J=11.5,1.2 \mathrm{~Hz}, 1 \mathrm{H}), 4.00-3.98(\mathrm{~m}, 1 \mathrm{H}), 3.94-3.90(\mathrm{~m}, 3 \mathrm{H})$, $3.39($ br s, $1 \mathrm{H}), 2.94-2.85(\mathrm{~m}, 1 \mathrm{H}), 2.26\left(\mathrm{~d}, J_{\mathrm{AB}}=14.4 \mathrm{~Hz}, 1 \mathrm{H}\right), 2.08-2.01(\mathrm{~m}, 2 \mathrm{H}), 1.99\left(\mathrm{~d}, J_{\mathrm{AB}}=\right.$ $14.4 \mathrm{~Hz}, 1 \mathrm{H}), 1.80-1.56(\mathrm{~m}, 6 \mathrm{H}), 1.49-1.41(\mathrm{~m}, 1 \mathrm{H}), 1.41-1.34(\mathrm{~m}, 1 \mathrm{H}) ;{ }^{13} \mathrm{C} \mathrm{NMR}(125 \mathrm{MHz}$, $\left.\mathrm{CDCl}_{3}\right) \square 133.2,132.8,109.6,80.3,64.8,63.4,50.3,46.9,43.9,34.8,29.4,24.3,23.3$; HRMS (EI) for $\mathrm{C}_{13} \mathrm{H}_{20} \mathrm{O}_{3}$ calcd 224.1413, found: $\mathrm{m} / \mathrm{z} 224.1412$. 
Tricyclic Sulfone 11. To a mixture of $9(83 \mathrm{mg}, 0.24 \mathrm{mmol})$ in $\mathrm{MeOH}(1 \mathrm{~mL})$ cooled to $0^{\circ} \mathrm{C}$ was added a mixture of OXONE ${ }^{\square}(295 \mathrm{mg})$ in $\mathrm{pH} 4$ buffer $(1 \mathrm{~mL}){ }^{6}$ After the addition, the cooling bath was removed and the slurry was stirred at r.t. for $10 \mathrm{~h}$. The mixture was diluted with water $(5 \mathrm{~mL})$ and $\mathrm{CHCl}_{3}(5 \mathrm{~mL})$. The biphasic mixture was transferred to a separatory funnel, separated, and the aqueous phase was extracted with $\mathrm{CHCl}_{3}(3 \times 5 \mathrm{~mL})$. The combined organic phase was washed with brine, dried with $\mathrm{MgSO}_{4}$ and the solvents were removed under reduced pressure. Sulfone 11 was obtained as a white crystalline solid (88 $\mathrm{mg}, 97 \%$ ) (homogenous by TLC and ${ }^{1} \mathrm{H}$ NMR analysis), and was used without further purification: $\mathrm{mp}$ 191-194 ${ }^{\circ} \mathrm{C}$; $\mathrm{R}_{f} 0.25$ (30\% EtOAc/hexanes); IR ( $\mathrm{CH}_{2} \mathrm{Cl}_{2}$ cast) $2956,1299,1145,1085 \mathrm{~cm}^{-1} ;{ }^{1} \mathrm{H}$ NMR $\left(500 \mathrm{MHz}, \mathrm{CDCl}_{3}\right) \square 7.76(\mathrm{~d}, J=8.4 \mathrm{~Hz}, 2 \mathrm{H}), 7.34(\mathrm{~d}, J=7.9 \mathrm{~Hz}, 2 \mathrm{H}), 4.46(\operatorname{app} \mathrm{d}, J=$ $2.9 \mathrm{~Hz}, 1 \mathrm{H}), 4.01$ (ddd, $J=8.0,6.5,4.4 \mathrm{~Hz}, 1 \mathrm{H}), 3.95-3.90(\mathrm{~m}, 1 \mathrm{H}), 3.85$ (app q, $J=7.0 \mathrm{~Hz}$, 1H), 3.78 (app q, $J=7.4 \mathrm{~Hz}, 1 \mathrm{H}), 3.51$ (dddd, $J=11.6,3.3,3.3,3.3 \mathrm{~Hz}, 1 \mathrm{H}), 2.44$ (s, 3H), 2.27 $(\mathrm{dd}, J=14.3,0.9 \mathrm{~Hz}, 1 \mathrm{H}), 2.10\left(\mathrm{~d}, J_{\mathrm{AB}}=14.3 \mathrm{~Hz}, 1 \mathrm{H}\right), 1.98-1.90(\mathrm{~m}, 2 \mathrm{H}), 1.80-1.50(\mathrm{~m}, 9 \mathrm{H})$; ${ }^{13} \mathrm{C}$ NMR $\left(125 \mathrm{MHz}, \mathrm{CDCl}_{3}\right) \square 144.7,135.2,129.9,129.4,117.3,92.7,79.5,67.1,65.4,64.8$, 47.2, 42.6, 39.7, 28.5, 25.2, 21.8, 20.9, 20.5.

Vinyl Sulfone 12. To a solution of $11(22 \mathrm{mg}, 0.058 \mathrm{mmol})$ in THF $(1.16 \mathrm{~mL})$ cooled to $-78^{\circ} \mathrm{C}$ (isopropanol/dry ice bath) was added dropwise via syringe $n \mathrm{BuLi}(35 \mu \mathrm{L}, 2.52 \mathrm{M}$ in hexanes). The solution initially turned pale yellow, then dark yellow-orange. The starting material was consumed after $20 \mathrm{~min}$ as ascertained by TLC, and the reaction was stirred an additional $30 \mathrm{~min}$. The cooling bath was removed and the reaction was immediately quenched by the addition of sat. $\mathrm{NH}_{4} \mathrm{Cl}$ solution $(4 \mathrm{~mL})$ and $\mathrm{Et}_{2} \mathrm{O}(5 \mathrm{~mL})$. The biphasic mixture was transferred to a separatory funnel, separated, and the aqueous phase was extracted with $\mathrm{Et}_{2} \mathrm{O}(3 \times 5 \mathrm{~mL})$. The combined organic phase was then washed with brine $(10 \mathrm{~mL})$, dried with $\mathrm{MgSO}_{4}$, filtered and the solvents were removed under reduced pressure. The resulting crude material was purified by radial chromatography $(2 \mathrm{~mm}$ plate, solvent ramp: $100 \mathrm{~mL}$ each of $20 \%, 30 \%, 40 \%$ EtOAc/hexanes) to yield 12 (16 mg, 75\%) as a white solid: $\mathrm{mp} 120-122{ }^{\circ} \mathrm{C}$; $\mathrm{R}_{f} 0.11(30 \%$ EtOAc/hexanes); IR ( $\mathrm{CH}_{2} \mathrm{Cl}_{2}$ cast) 3534, 2948, 1301, 1143, $1086 \mathrm{~cm}^{-1} ;{ }^{1} \mathrm{H}$ NMR (500 MHz, $\left.\mathrm{CDCl}_{3}\right) \square 7.75(\mathrm{~d}, J=8.4 \mathrm{~Hz}, 2 \mathrm{H}), 7.33(\mathrm{~d}, J=8.3 \mathrm{~Hz}, 2 \mathrm{H}), 6.92$ (app br s, 1H), 4.02-3.92 (m, $3 \mathrm{H}), 3.87-3.83(\mathrm{~m}, 1 \mathrm{H}), 3.30$ (br s, $1 \mathrm{H}), 3.16$ (ddd, $J=14.2,12.3,6.7 \mathrm{~Hz}, 1 \mathrm{H}), 2.44(\mathrm{~s}, 3 \mathrm{H}), 2.31$ $(\mathrm{ddd}, J=14.8,7.3,1.5 \mathrm{~Hz}, 1 \mathrm{H}), 2.26\left(\mathrm{~d}, J_{\mathrm{AB}}=14.6 \mathrm{~Hz}, 1 \mathrm{H}\right), 2.06\left(\mathrm{~d}, J_{\mathrm{AB}}=14.6 \mathrm{~Hz}, 1 \mathrm{H}\right), 1.76-$ $1.73(\mathrm{~m}, 2 \mathrm{H}), 1.67-1.57(\mathrm{~m}, 3 \mathrm{H}), 1.51-1.46(\mathrm{~m}, 1 \mathrm{H}), 1.35-1.19(\mathrm{~m}, 3 \mathrm{H}) ;{ }^{13} \mathrm{C} \mathrm{NMR}(100 \mathrm{MHz}$, $\left.\mathrm{CDCl}_{3}\right) \square 144.9,144.8,140.1,136.1,130.1,128.7,108.8,79.8,65.5,63.7,50.2,47.1,44.0,34.5$, 28.8, 23.4, 23.2, 21.9; HRMS (EI) for $\mathrm{C}_{20} \mathrm{H}_{26} \mathrm{O}_{5} \mathrm{~S}$ calcd 378.1501, found: $\mathrm{m} / \mathrm{z} 378.1495$.

$(1 S *, 3 S *, 6 R *)-3-M e t h o x y-2-0 x a b i c y c l[4.3 .0]$ nonane-1-acetic Acid. To a solution of hemiacetal 2a $(410 \mathrm{mg}, 1.69 \mathrm{mmol})$ in THF $(3.0 \mathrm{~mL})$ and methanol $(3.0 \mathrm{~mL})$ was added a $2 \mathrm{M}$ solution of $\mathrm{LiOH}(1.7 \mathrm{~mL})$. The reaction was stirred for 16 hours at r.t., during which time the reaction mixture turned slightly yellow. The reaction was diluted with water $(15 \mathrm{~mL})$ and $\mathrm{Et}_{2} \mathrm{O}$ $(15 \mathrm{~mL})$ and transferred to a separatory funnel. The layers were separated and the aqueous layer was washed with ether $(15 \mathrm{~mL})$. The aqueous layer was then acidified with $0.5 \mathrm{M} \mathrm{HCl}$ to $\mathrm{pH} \sim 3$, resulting in a cloudy suspension. To this was added ethyl acetate $(20 \mathrm{~mL})$ and the resulting layers separated. The aqueous layer was washed with 3 portions of ethyl acetate $(20 \mathrm{~mL})$ and the combined organic extracts were washed with water then brine, dried over magnesium sulfate, filtered and concentrated to yield the acid, as a yellow oil $(307 \mathrm{mg}, 85 \%)$ : IR $\left(\mathrm{CH}_{2} \mathrm{Cl}_{2}\right.$ cast) 
3500-2400, 2946, 2891, 2680, 1704, 1451, 1408, 1391, 1363, 1335, 1322, $1307 \mathrm{~cm}^{-1}$; ${ }^{1} \mathrm{H}$ NMR $\left(500 \mathrm{MHz}, \mathrm{CDCl}_{3}\right) \square 10.90$ (br. s, $\left.1 \mathrm{H}\right), 4.66-4.64(\mathrm{~m}, 1 \mathrm{H}), 3.41(\mathrm{~s}, 3 \mathrm{H}), 2.94\left(\mathrm{~d}, J_{\mathrm{AB}}=14.1 \mathrm{~Hz}\right.$, $1 \mathrm{H}), 2.35\left(\mathrm{~d}, J_{\mathrm{AB}}=14.1 \mathrm{~Hz}, 1 \mathrm{H}\right), 2.16(\mathrm{~m}, 1 \mathrm{H}), 1.91-1.80(\mathrm{~m}, 3 \mathrm{H}), 1.78-1.72(\mathrm{~m}, 4 \mathrm{H}), 1.66-$ $1.58(\mathrm{~m}, 3 \mathrm{H}) ;{ }^{13} \mathrm{C} \mathrm{NMR}\left(125 \mathrm{MHz}, \mathrm{CDCl}_{3}\right) \square 174.9,98.9,83.8,56.0,41.2,41.0,38.9,28.1,26.2$, 21.7, 21.5; HRMS (EI) calcd for $\mathrm{C}_{11} \mathrm{H}_{18} \mathrm{O}_{4}\left(\mathrm{M}^{+}\right)$214.1205, found 214.1192; Anal. Calcd for $\mathrm{C}_{11} \mathrm{H}_{18} \mathrm{O}_{4}$ : C, 61.66; H, 8.73. Found: $\mathrm{C}, 61.31 ; \mathrm{H}, 8.47$.

$\left(1 S^{*}, 3 S^{*}, 6 R^{*}\right)$-3-Methoxy-2-oxabicycl[4.3.0]nonane-1-acetic Acid Mixed Anhydride. To a solution of the acid $(100 \mathrm{mg}, 0.47 \mathrm{mmol})$ in $\mathrm{Et}_{2} \mathrm{O}(2 \mathrm{~mL})$ at $0^{\circ} \mathrm{C}$ was added $\mathrm{Et}_{3} \mathrm{~N}(68 \square \mathrm{L}, 0.49$ $\mathrm{mmol})$ followed by isobutyl chloroformate $(65 \square \mathrm{L}, 0.49 \mathrm{mmol})$ and the reaction stirred for 4 hours, resulting in an off-white precipitate. The reaction mixture was filtered through a fritted filter (D), the residue was rinsed with $\mathrm{Et}_{2} \mathrm{O}(20 \mathrm{~mL})$ and the combined filtrates were concentrated to give the anydride as a yellow oil (149 mg, 100\%) used directly in the next step: $\mathrm{R}_{f} 0.66(30 \%$ EtOAc/hexanes); IR ( $\mathrm{CH}_{2} \mathrm{Cl}_{2}$ cast) 2956, 2874, 1819, 1735, 1457, 1392, 1369, 1336, 13071230 , $1207 \mathrm{~cm}^{-1} ;{ }^{1} \mathrm{H}$ NMR $\left(500 \mathrm{MHz}, \mathrm{CDCl}_{3}\right) \square 4.60(\mathrm{dd}, J=8.8,3.0 \mathrm{~Hz}, 1 \mathrm{H}), 4.04(\mathrm{~d}, J=6.7 \mathrm{~Hz}$, $2 \mathrm{H}), 3.42(\mathrm{~s}, 3 \mathrm{H}), 3.08\left(\mathrm{~d}, J_{\mathrm{AB}}=13.6 \mathrm{~Hz}, 1 \mathrm{H}\right), 2.42\left(\mathrm{~d}, J_{\mathrm{AB}}=13.6 \mathrm{~Hz}, 1 \mathrm{H}\right), 2.16(\mathrm{~m}, 1 \mathrm{H}), 2.01$ (sept, $J=6.7 \mathrm{~Hz}, 1 \mathrm{H}), 1.94-1.83(\mathrm{~m}, 2 \mathrm{H}), 1.82-1.68(\mathrm{~m}, 5 \mathrm{H}), 1.64-1.53(\mathrm{~m}, 3 \mathrm{H}), 0.97(\mathrm{~d}, J=$ 6.7 Hz, 6H); ${ }^{13} \mathrm{C}$ NMR (125 MHz, $\left.\mathrm{CDCl}_{3}\right) \square 165.4,149.3,98.7,83.5,75.7,56.2,41.2,40.9,39.7$, 28.0, 27.8, 25.9, 21.9, 21.8, 19.0; HRMS (EI) calcd for $\mathrm{C}_{16} \mathrm{H}_{26} \mathrm{O}_{6}\left(\mathrm{M}^{+}\right)$314.1729, found 314.1721 .

Diazoketone 4a. Into a solution of freshly prepared diazomethane (12 mmol) in $\mathrm{Et}_{2} \mathrm{O}(40 \mathrm{~mL})$ at $-15^{\circ} \mathrm{C}$ was added a solution of the mixed anhydride $(250 \mathrm{mg}, 0.80 \mathrm{mmol})$ in $\mathrm{Et}_{2} \mathrm{O}(10 \mathrm{~mL})$, and the resulting mixture was allowed to stir overnight as the cold bath expired. A stream of $\mathrm{N}_{2}$ was applied to the system to allow for slow evaporation of both excess diazomethane and solvent, and the resulting yellow oil was diluted in ether, and passed through a short pad of silica gel in a fritted filter, eluting with ether. This was then concentrated and the resulting oil purified by radial chromatography (2 mm plate, solvent ramp: $100 \mathrm{~mL}$ each of $5 \%, 10 \%$ then $15 \%$ EtOAc/hexanes until the product was recovered) to yield starting material (152 $\mathrm{mg})$ as well as 4a (51 mg, 22\%; 70\% BRSM) as a yellow oil: $\mathrm{R}_{f} 0.33$ (3:7 EtOAc/hexanes); IR $\left(\mathrm{CH}_{2} \mathrm{Cl}_{2}\right.$ cast) 3082, 2953, 2869, 2101, 1733, 1637, 1457, 1364, 1226, $1187 \mathrm{~cm}^{-1} ;{ }^{1} \mathrm{H}$ NMR $\left(500 \mathrm{MHz},-20^{\circ} \mathrm{C}\right.$, $\left.\mathrm{CDCl}_{3}\right) \square 5.50(\mathrm{~s}, 1 \mathrm{H}), 4.64(\mathrm{dd}, J=8.4,3.1 \mathrm{~Hz}, 1 \mathrm{H}), 3.46(\mathrm{~s}, 3 \mathrm{H}), 2.96\left(\mathrm{~d}, J_{\mathrm{AB}}=13.7 \mathrm{~Hz}, 1 \mathrm{H}\right)$, $2.33\left(\mathrm{~d}, J_{\mathrm{AB}}=13.7 \mathrm{~Hz}, 1 \mathrm{H}\right), 2.09(\mathrm{ddd}, J=12.8,8.2,4.0 \mathrm{~Hz}, 1 \mathrm{H}), 1.86(\mathrm{~m}, 2 \mathrm{H}), 1.82-1.66(\mathrm{~m}$, $5 \mathrm{H}), 1.66-1.54(\mathrm{~m}, 3 \mathrm{H}) ;{ }^{13} \mathrm{C}$ NMR $\left(125 \mathrm{MHz},-60^{\circ} \mathrm{C}, \mathrm{CDCl}_{3}\right.$, $) \square$ 193.0, 98.2, 83.8, 56.7, 56.6, 46.0 41.1, 39.2, 26.8, 25.2, 21.4, 21.0; HRMS (EI) calcd for $\mathrm{C}_{12} \mathrm{H}_{17} \mathrm{~N}_{2} \mathrm{O}_{3}\left(\mathrm{M}-\mathrm{H}^{+}\right)$237.1239, found 237.1225 .

8-Methoxy-12-oxatricyclo[7.2.1.0 $\left.{ }^{1,5}\right]$ undecan-10-one 7a. To a refluxing solution of $\mathrm{Cu}(\text { hfacac })_{2}(9.4 \mathrm{mg}, 0.02 \mathrm{mmol}, 10 \mathrm{~mol} \%)$ in $\mathrm{CH}_{2} \mathrm{Cl}_{2}(15 \mathrm{~mL})$ was added a solution of $4 \mathbf{a}$ (46.9 $\mathrm{mg}, 0.20 \mathrm{mmol})$ in $\mathrm{CH}_{2} \mathrm{Cl}_{2}(5 \mathrm{~mL})$, and the resulting mixture was stirred at reflux until consumption of $\mathbf{4 a}(\sim 30 \mathrm{~min})$, after which the reaction mixture was cooled to room temperature and quenched with $0.5 \mathrm{M} \mathrm{K}_{2} \mathrm{CO}_{3}(10 \mathrm{~mL})$. The layers were separated and the aqueous phase extracted with $\mathrm{CH}_{2} \mathrm{Cl}_{2}(2 \times 10 \mathrm{~mL})$. The organic extracts were combined and washed with water and brine, dried with magnesium sulfate, filtered and concentrated. The crude product was purified by column chromatography (30\% EtOAc/hexanes) to give 7a, a yellow solid, (34 mg), in $82 \%$ yield: m.p. $41-43{ }^{\circ} \mathrm{C}, \mathrm{R}_{f} 0.44$ (3:7 EtOAc/hexanes); IR ( $\mathrm{CH}_{2} \mathrm{Cl}_{2}$ cast) 2937, 2867, 
2823, 1755, 1450, 1403, 1366, 1342, 1299, $1235 \mathrm{~cm}^{-1} ;{ }^{1} \mathrm{H}$ NMR $\left(500 \mathrm{MHz}, \mathrm{CDCl}_{3}\right) \square 4.05(\mathrm{~s}$, $1 \mathrm{H}), 3.50(\mathrm{ddd}, J=6.2,4.2,1.2 \mathrm{~Hz}, 1 \mathrm{H}), 3.35(\mathrm{~s}, 3 \mathrm{H}), 2.73\left(\mathrm{~d}, J_{\mathrm{AB}}=17.7 \mathrm{~Hz}, 1 \mathrm{H}\right), 2.37\left(\mathrm{~d}, J_{\mathrm{AB}}=\right.$ $17.7 \mathrm{~Hz}, 1 \mathrm{H}), 2.09(\mathrm{~m}, 1 \mathrm{H}), 2.02-1.92(\mathrm{~m}, 2 \mathrm{H}), 1.89-1.81(\mathrm{~m}, 2 \mathrm{H}), 1.79-1.71(\mathrm{~m}, 2 \mathrm{H}), 1.66$ $(\mathrm{m}, 1 \mathrm{H}), 1.56(\mathrm{~m}, 1 \mathrm{H}), 1.48(\mathrm{ddd}, J=14.5,10.2,4.2 \mathrm{~Hz}, 1 \mathrm{H}), 1.37$ (ddd, $J=13.7,10.0,3.2 \mathrm{~Hz}$, $1 \mathrm{H}) ;{ }^{13} \mathrm{C}$ NMR $\left(125 \mathrm{MHz}, \mathrm{CDCl}_{3}\right) \square 216.5,90.9$, 83.1, 81.6, 56.6, 51.3, 49.0, 40.4, 32.1, 27.0, 23.9, 23.5; HRMS (EI) calcd for $\mathrm{C}_{12} \mathrm{H}_{18} \mathrm{O}_{3}\left(\mathrm{M}^{+}\right)$210.1256, found 210.1249; Anal. Calcd for $\mathrm{C}_{12} \mathrm{H}_{18} \mathrm{O}_{3}$ : C, 68.60; H, 8.60. Found: C, 68.20; H, 9.06.

1. Diazoketones and especially diazomethane present special safety hazards. The reader is referred to Aldrich technical bulletin AL-180, Diazald, MNNG and Diazomethane Generators, Aldrich Chemical Co., Milwaukee, WI; available on the internet in pdf format at http://www.sigmaaldrich.com/aldrich/bulletin/AL-180.pdf.

2 Picotin, G.; Miginiac, P. J. Org. Chem. 1987, 52, 4796.

3 Ando, S.; Minor, K. P.; Overman, L. E. J. Org. Chem. 1997, 63, 6379.

4 Mudryk, B.; Cohen, T. Org. Synth. 1995, 72, 173.

5 Rychnovsky, S. D.; Buckmelter, A. J.; Dahankar, V. H.; Skalitzky, D. J. J. Org. Chem. 1999, 64, 6849.

6 Trost, B. M.; Curran, D. P. Tetrahedron Lett. 1981, 22, 1287. 

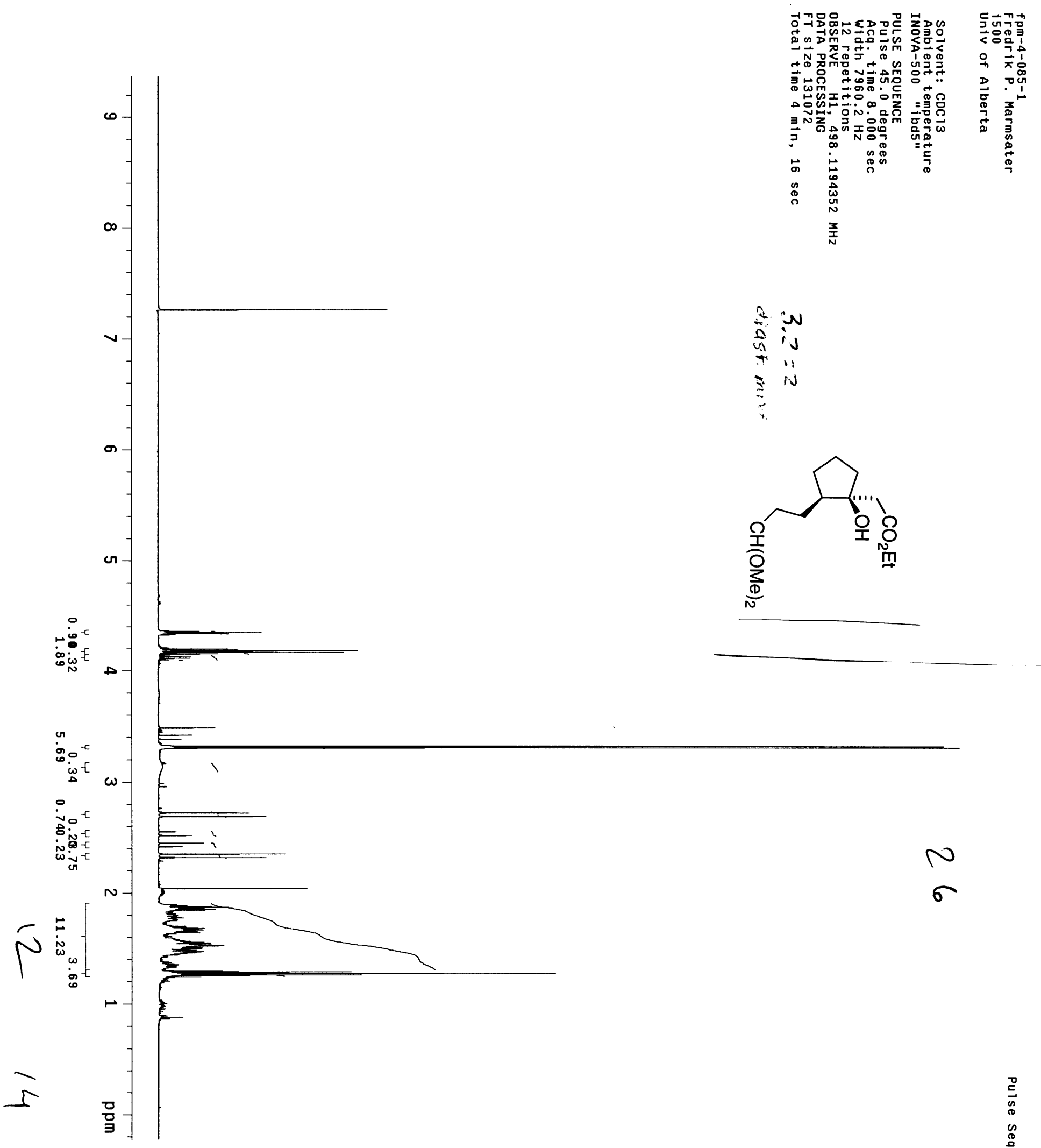


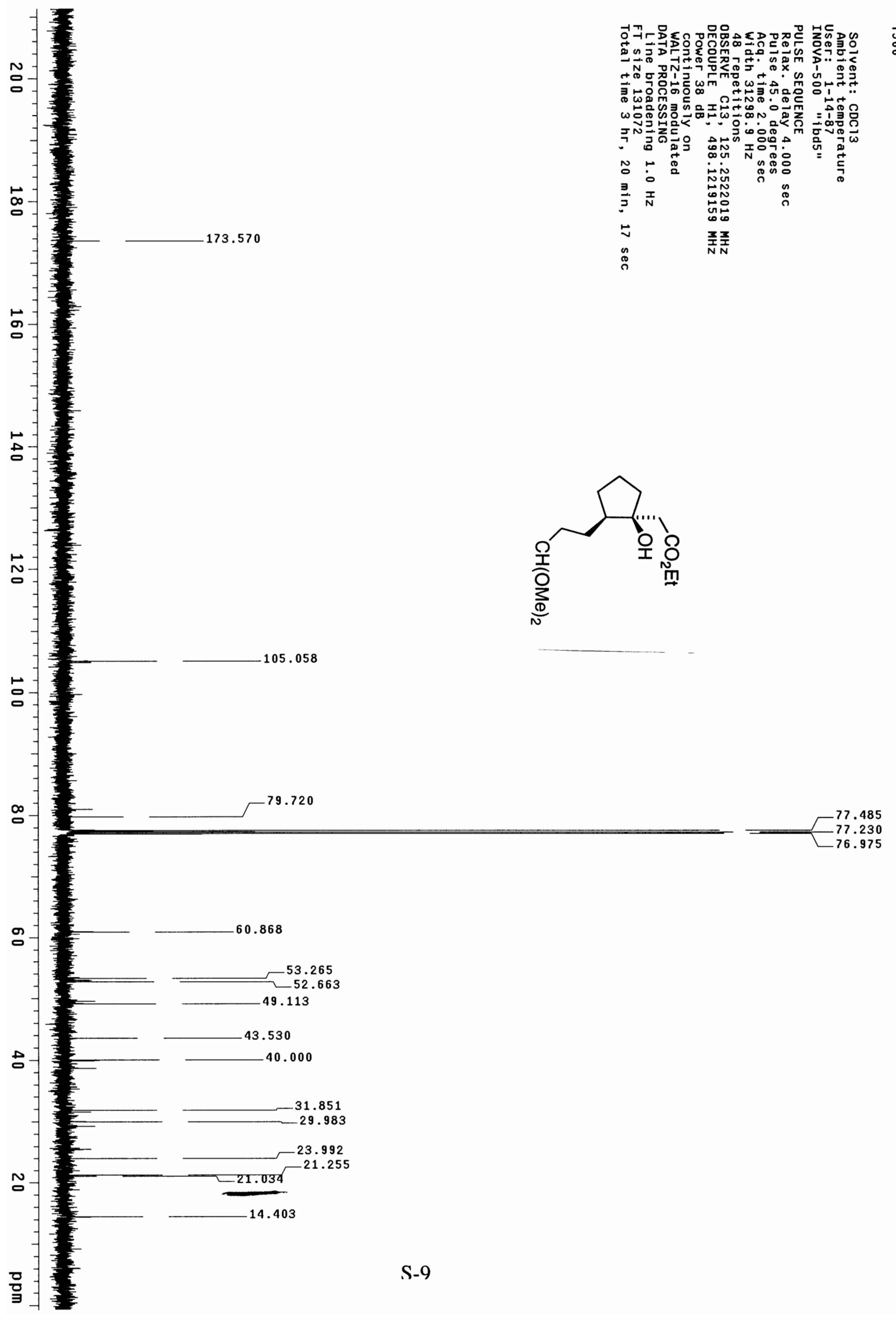




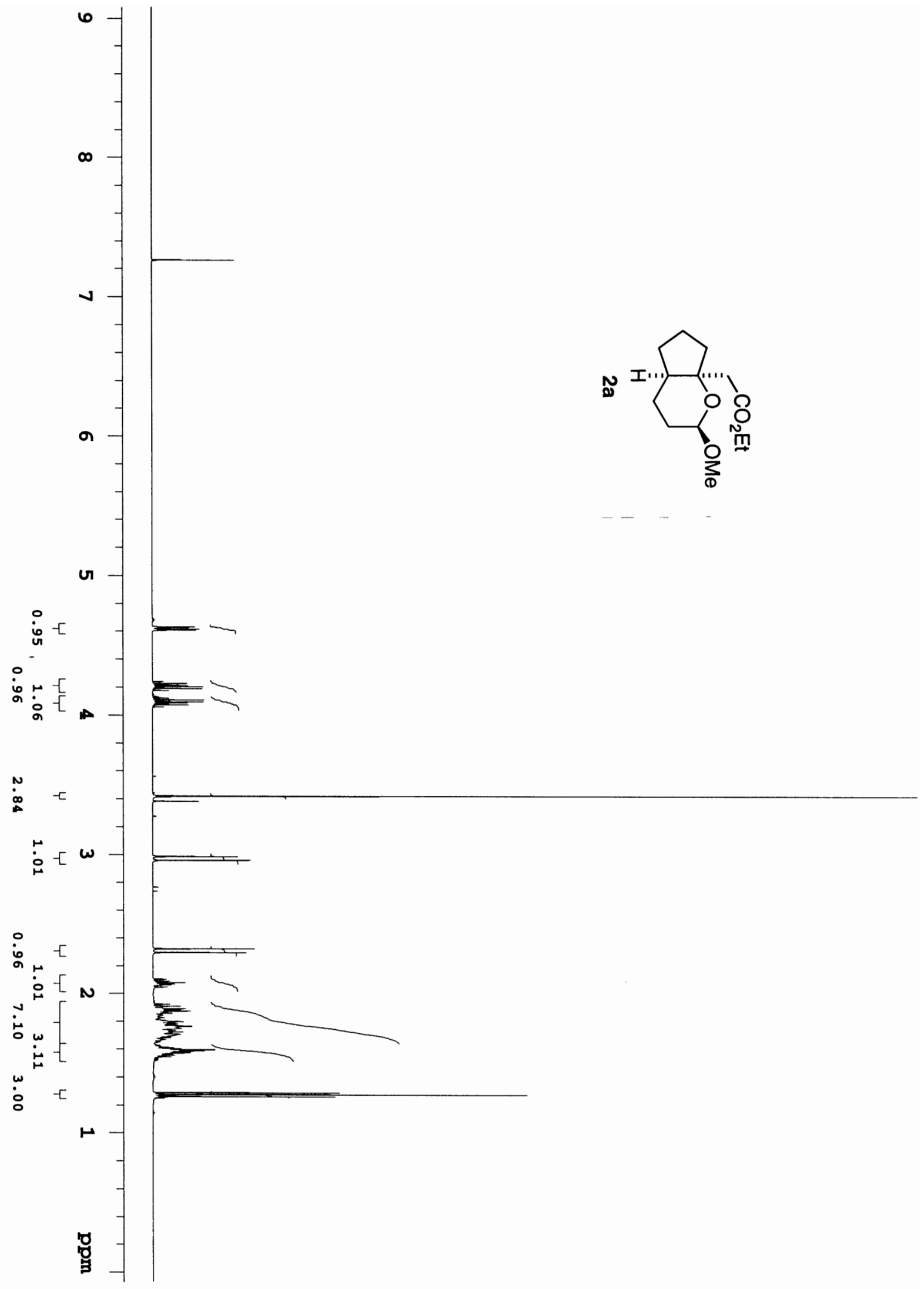




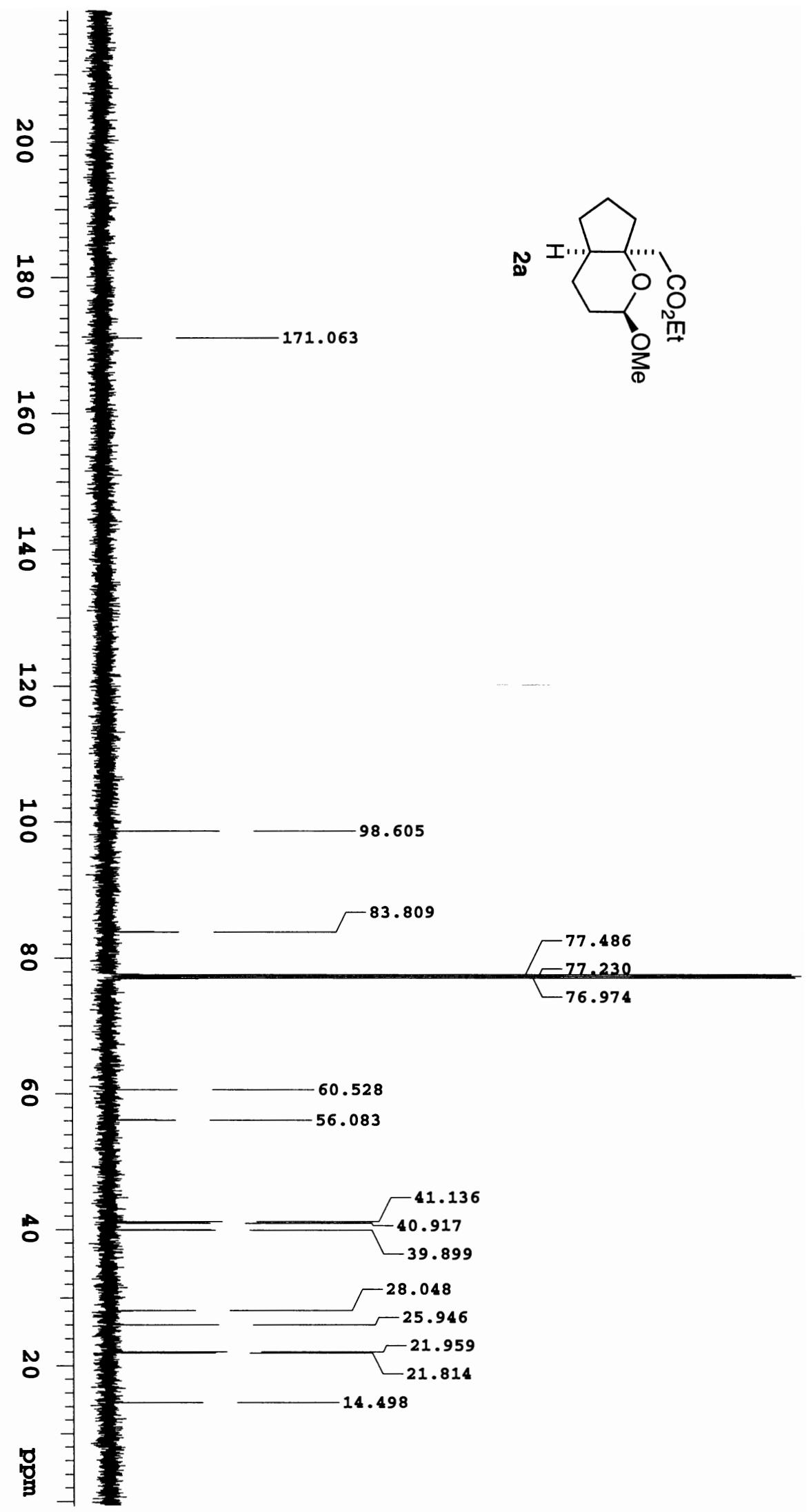

S-11 


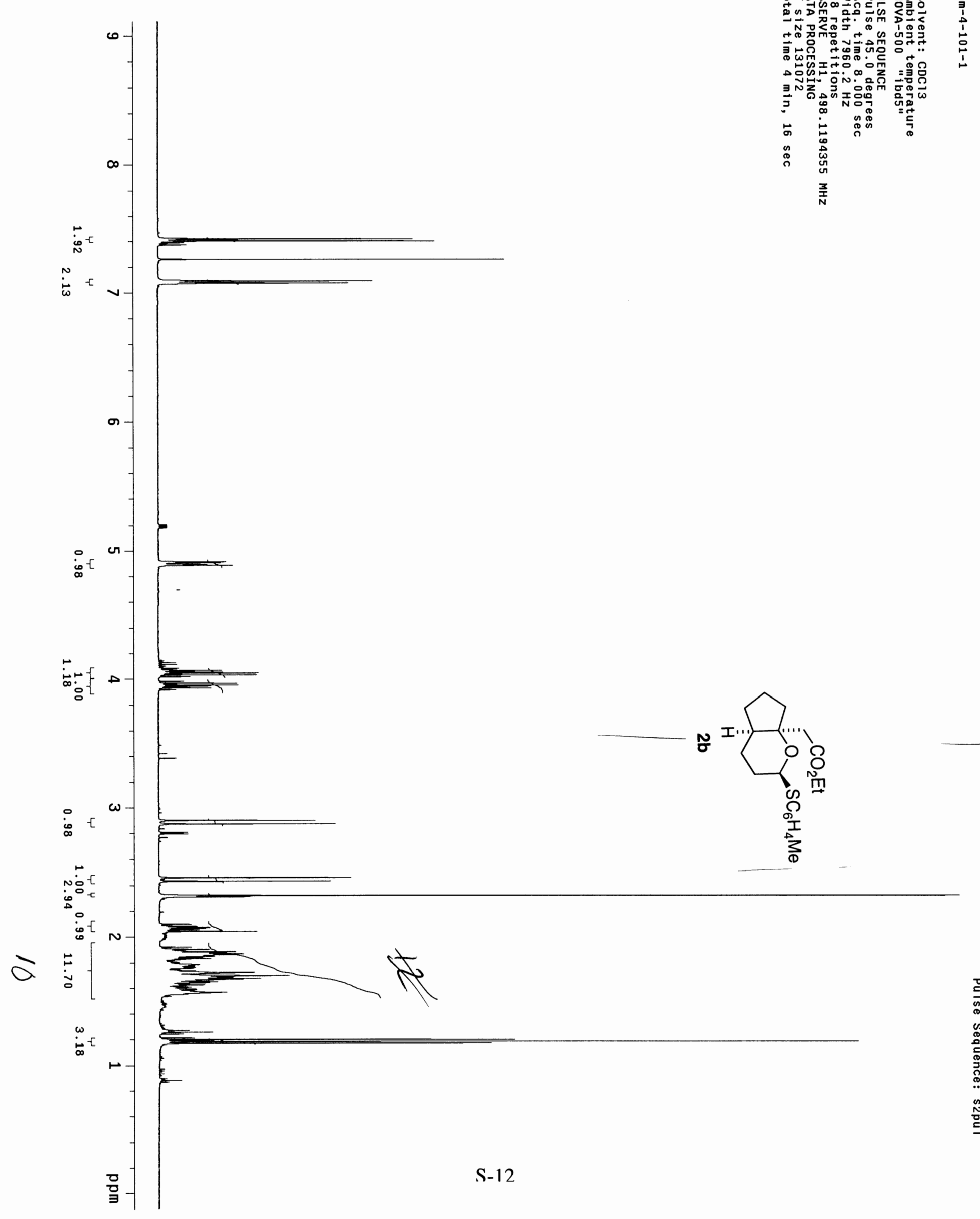




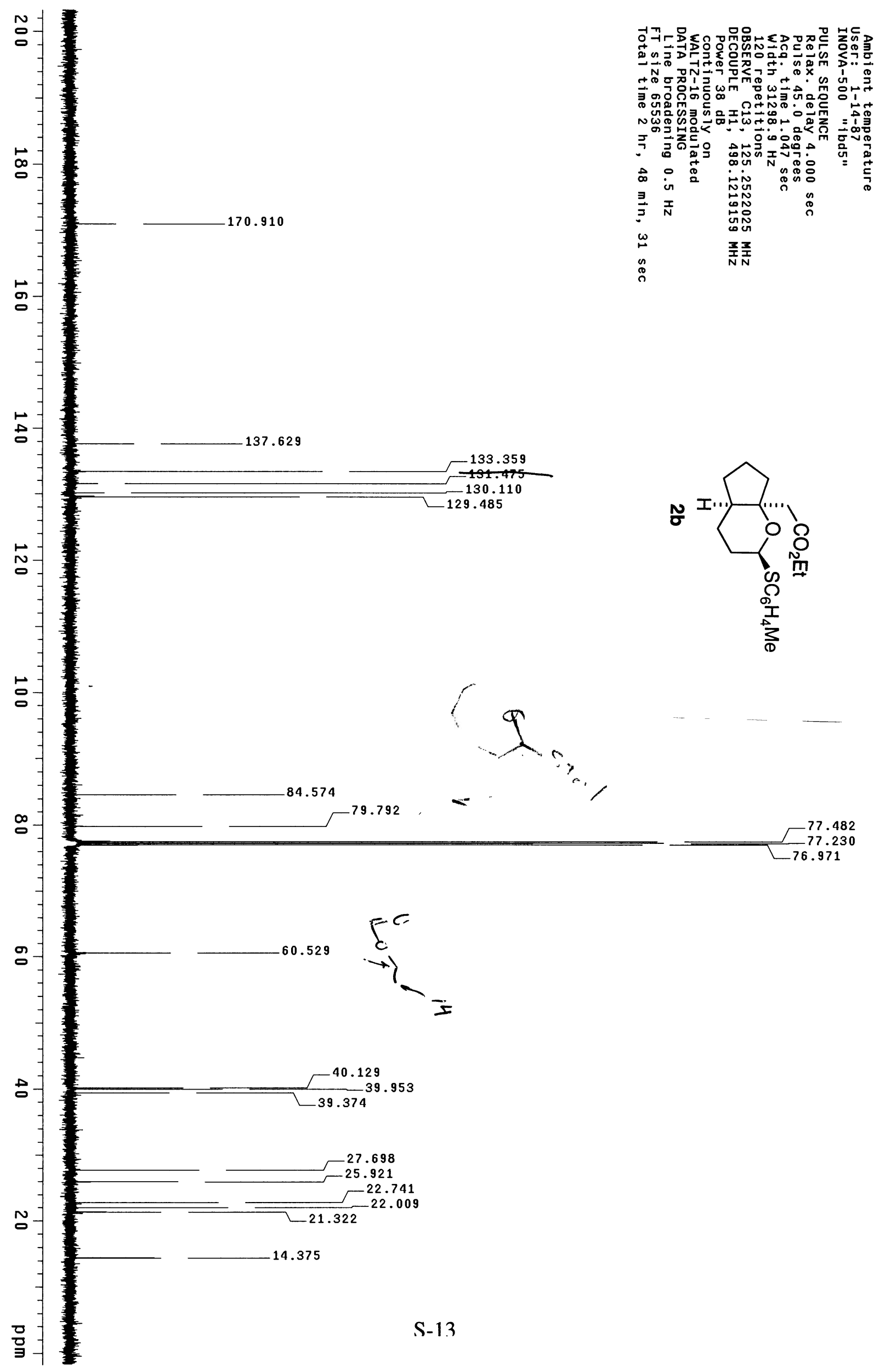



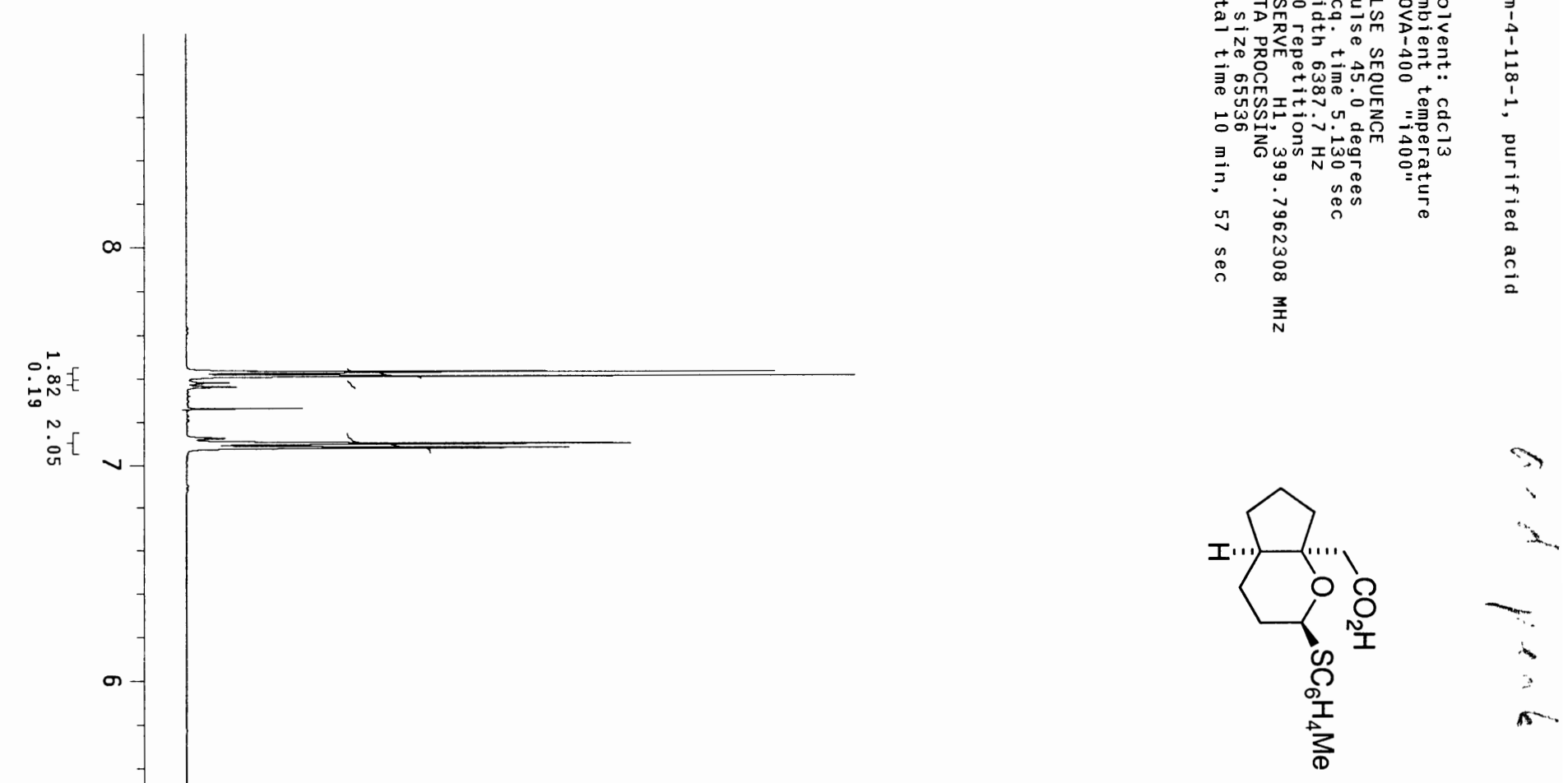


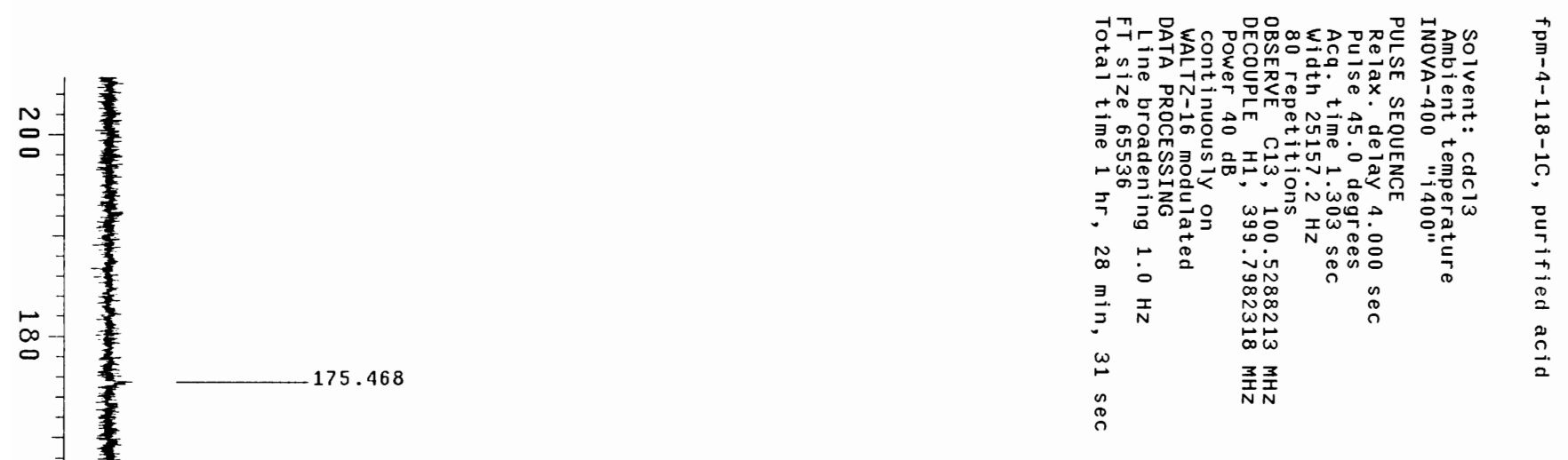

占

点
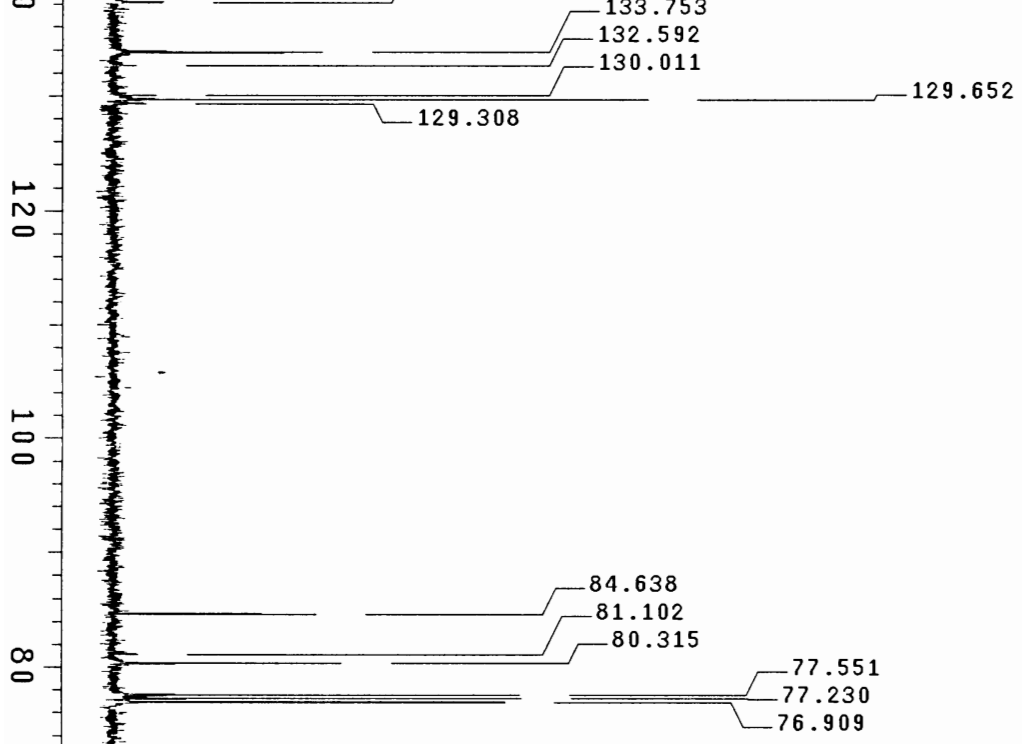

or

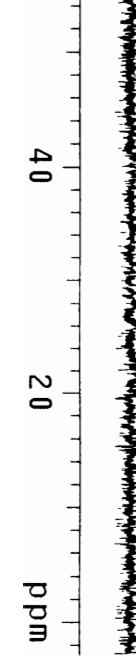

$-40.441$ 39.785

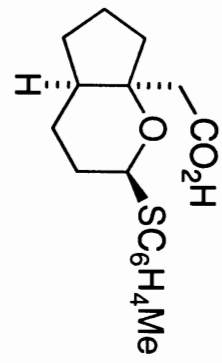




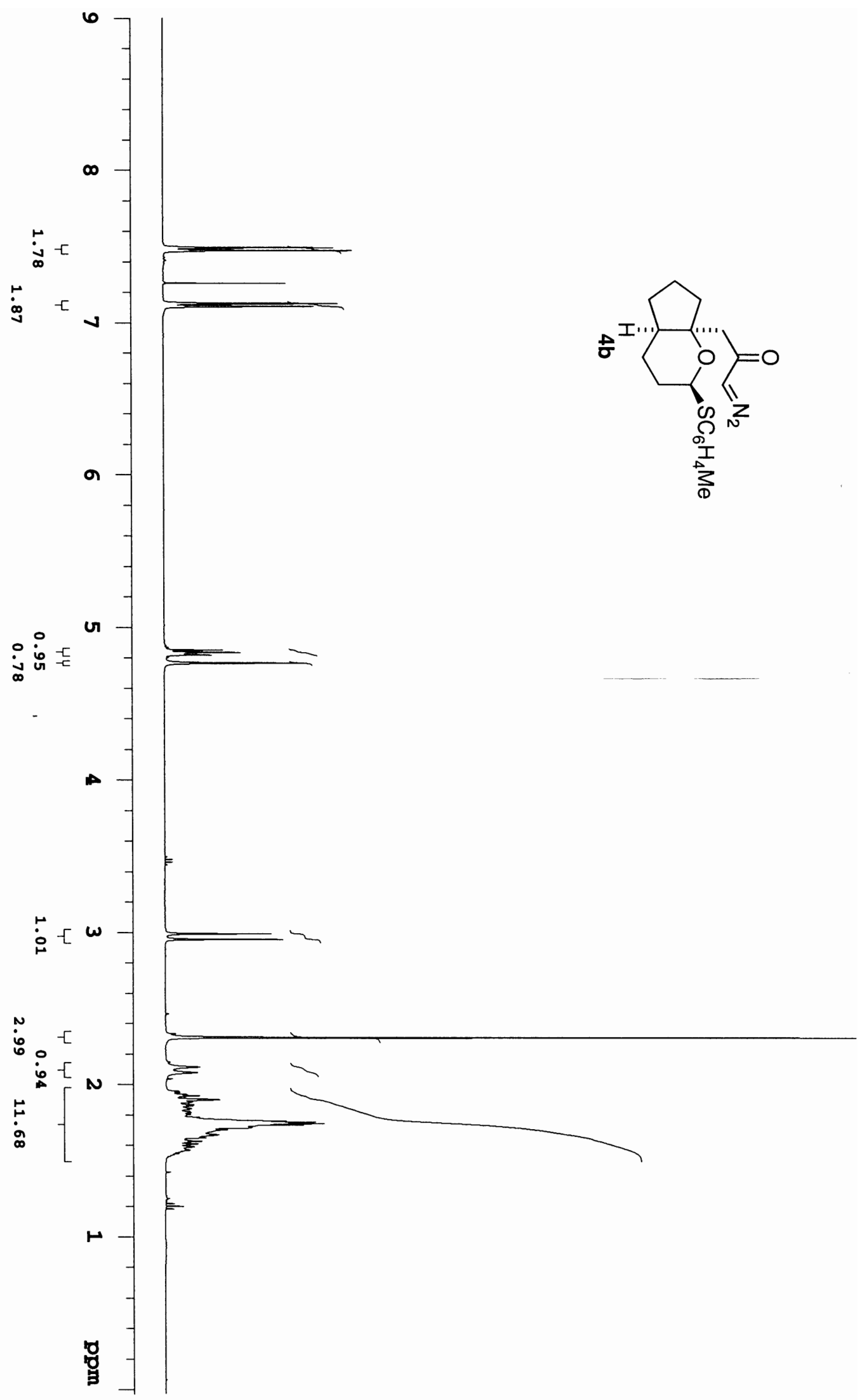




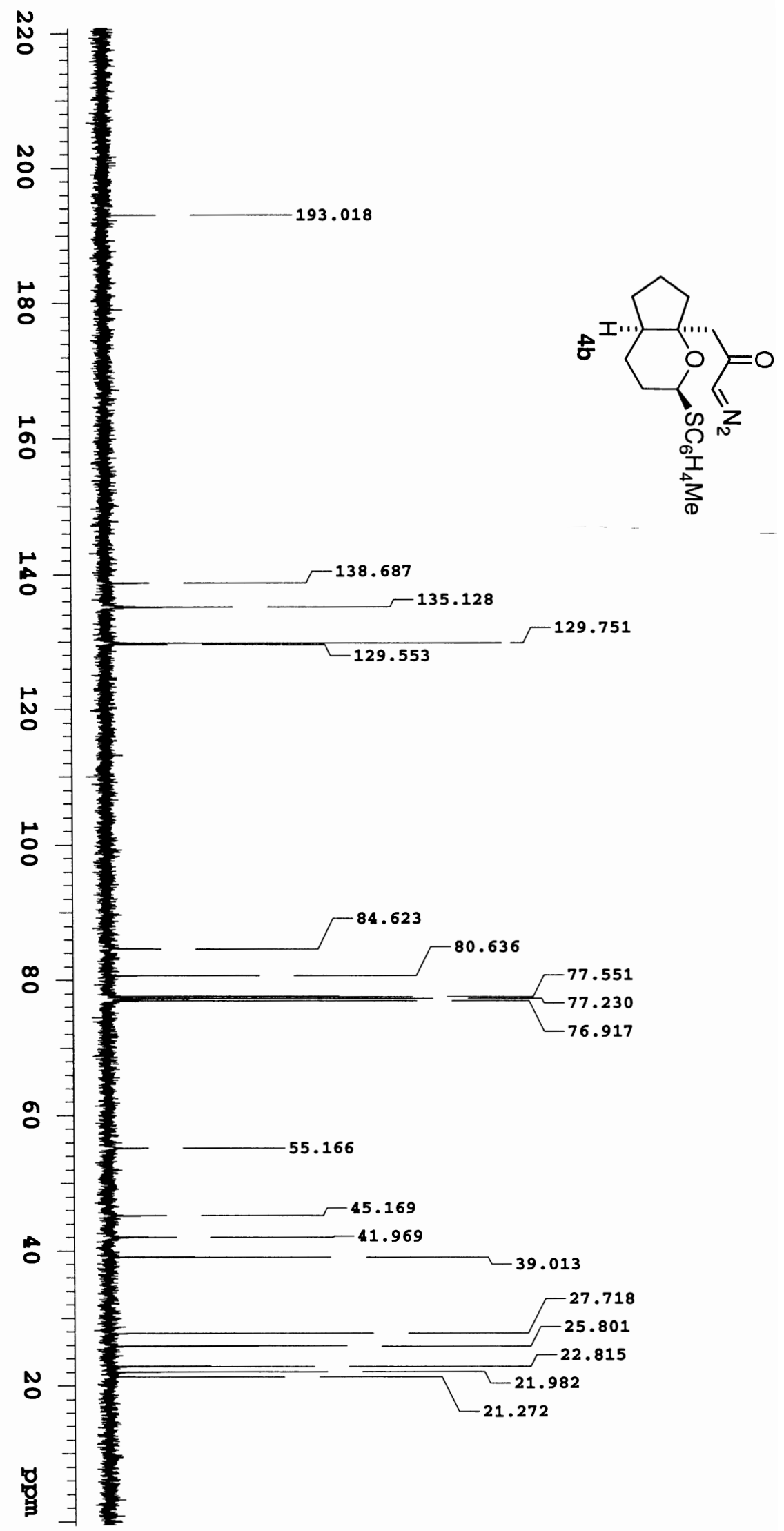

S-17 


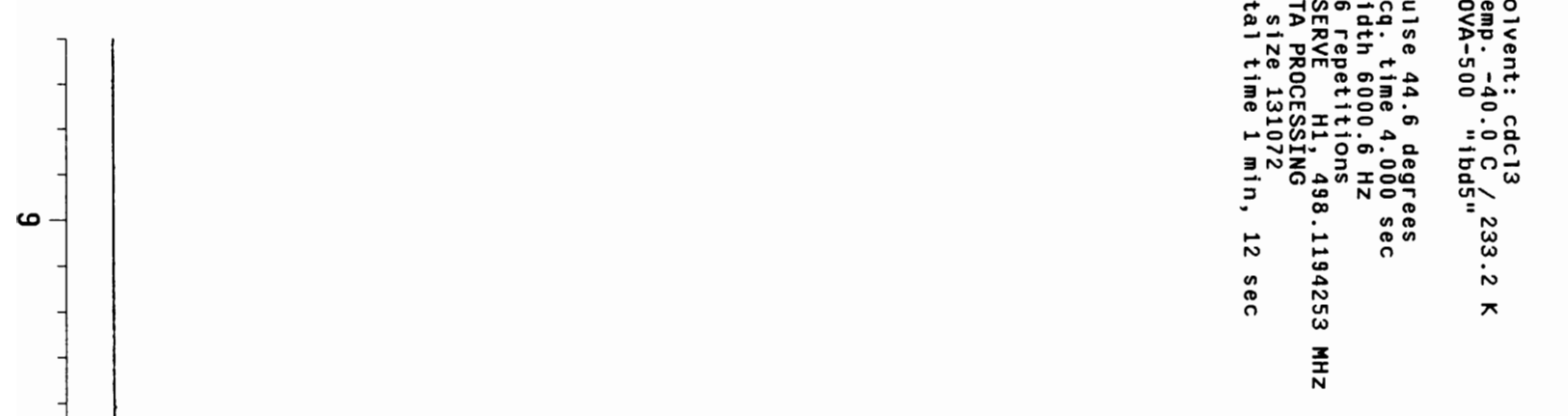

$\infty$

a
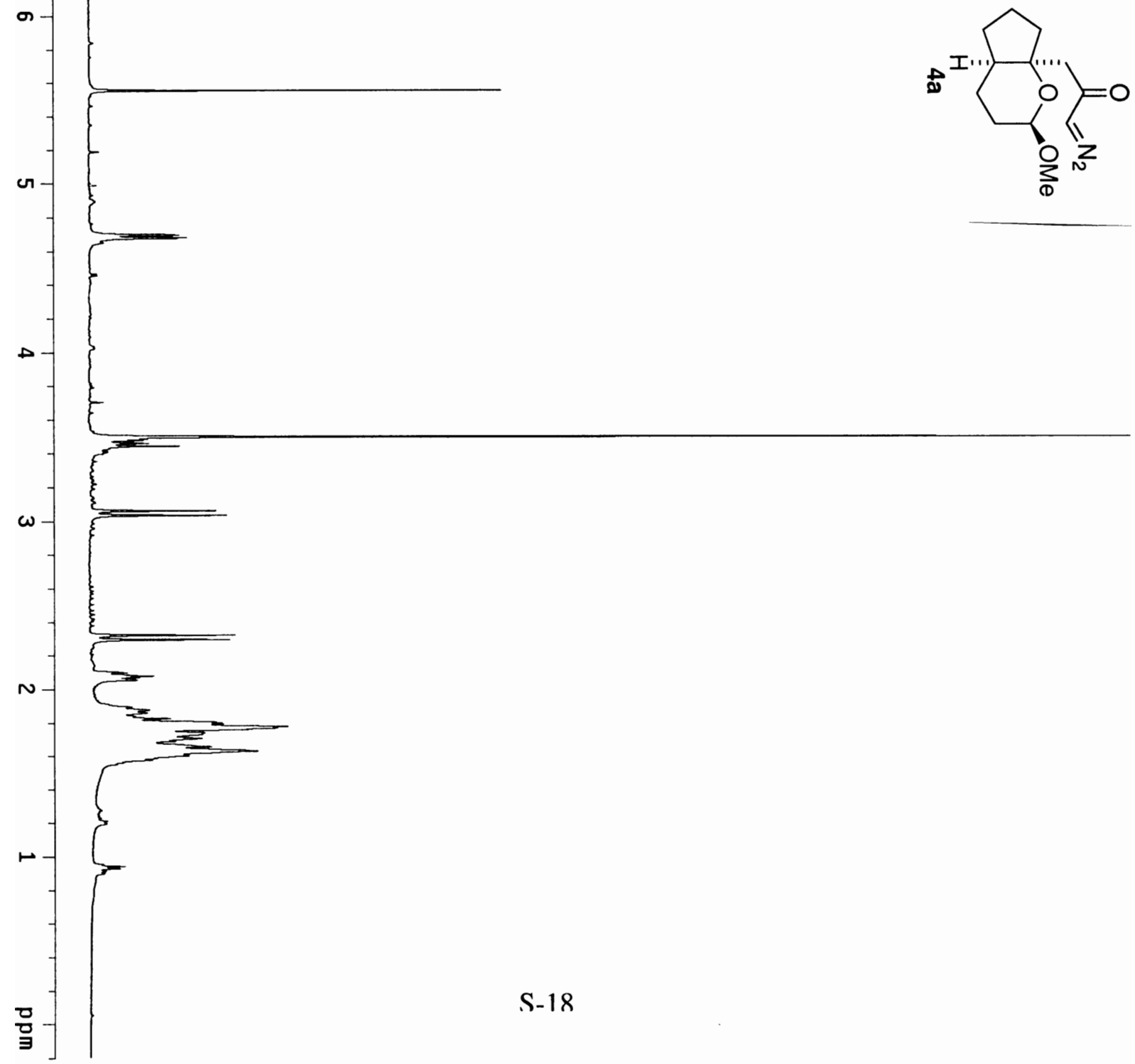


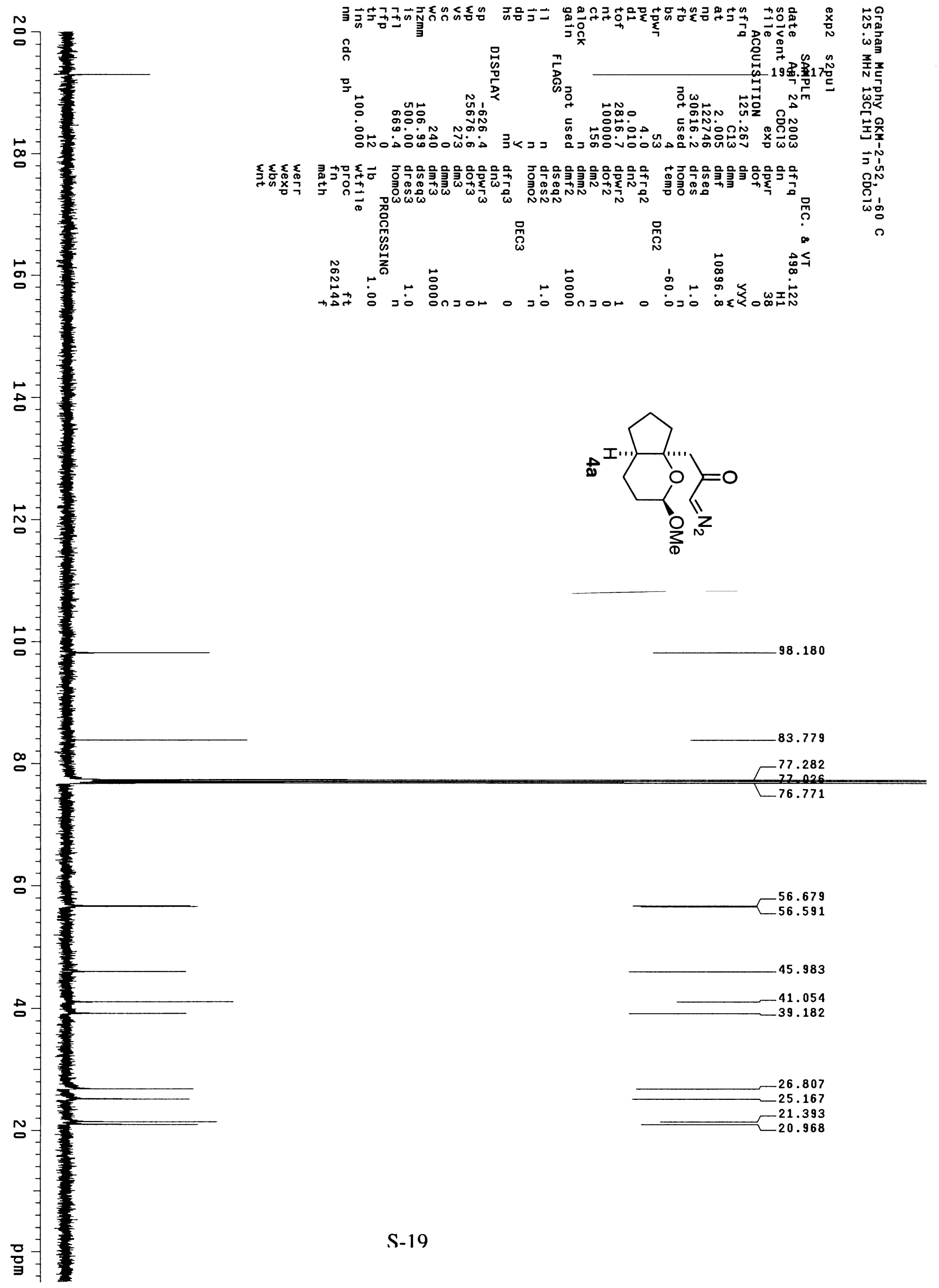




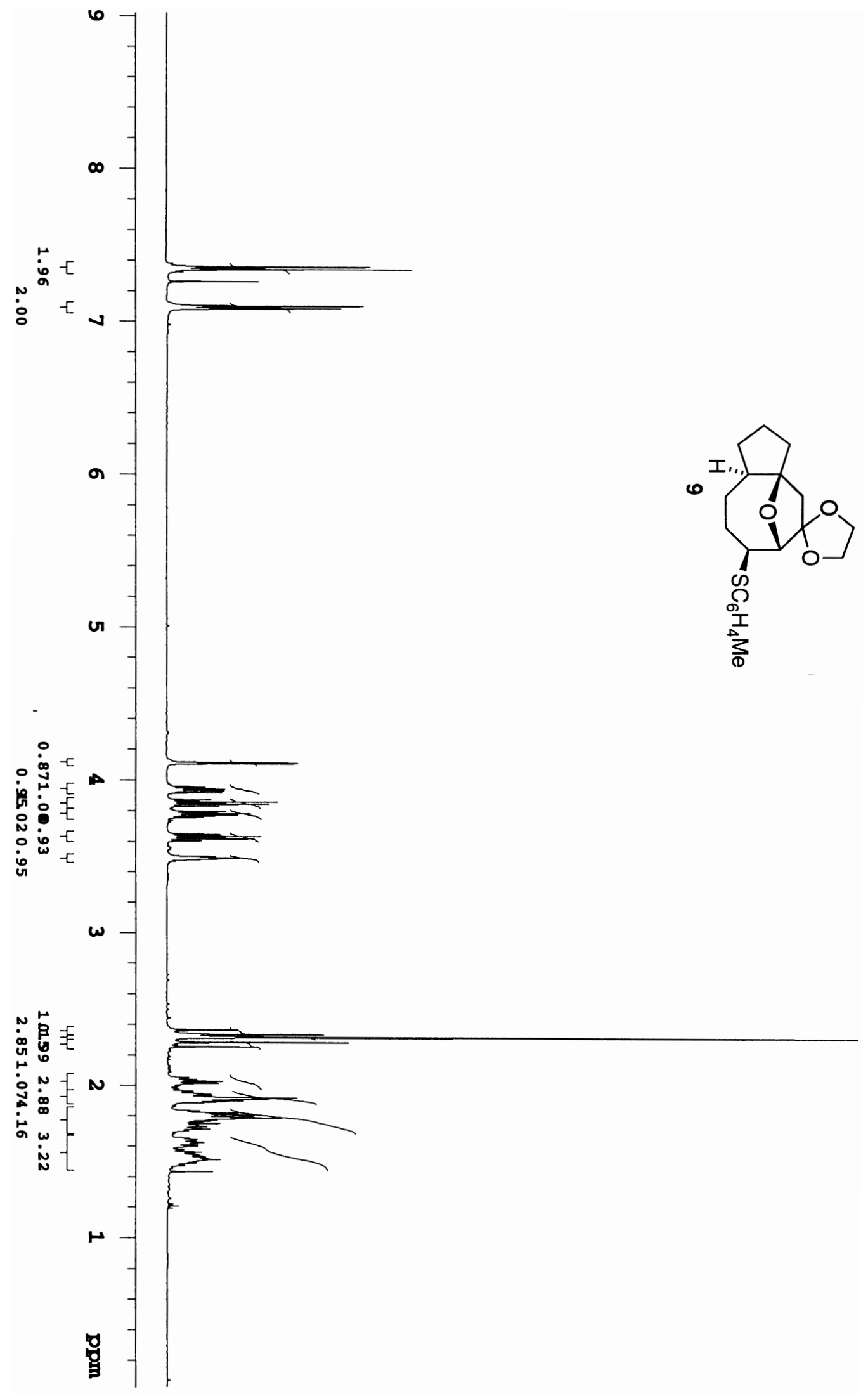




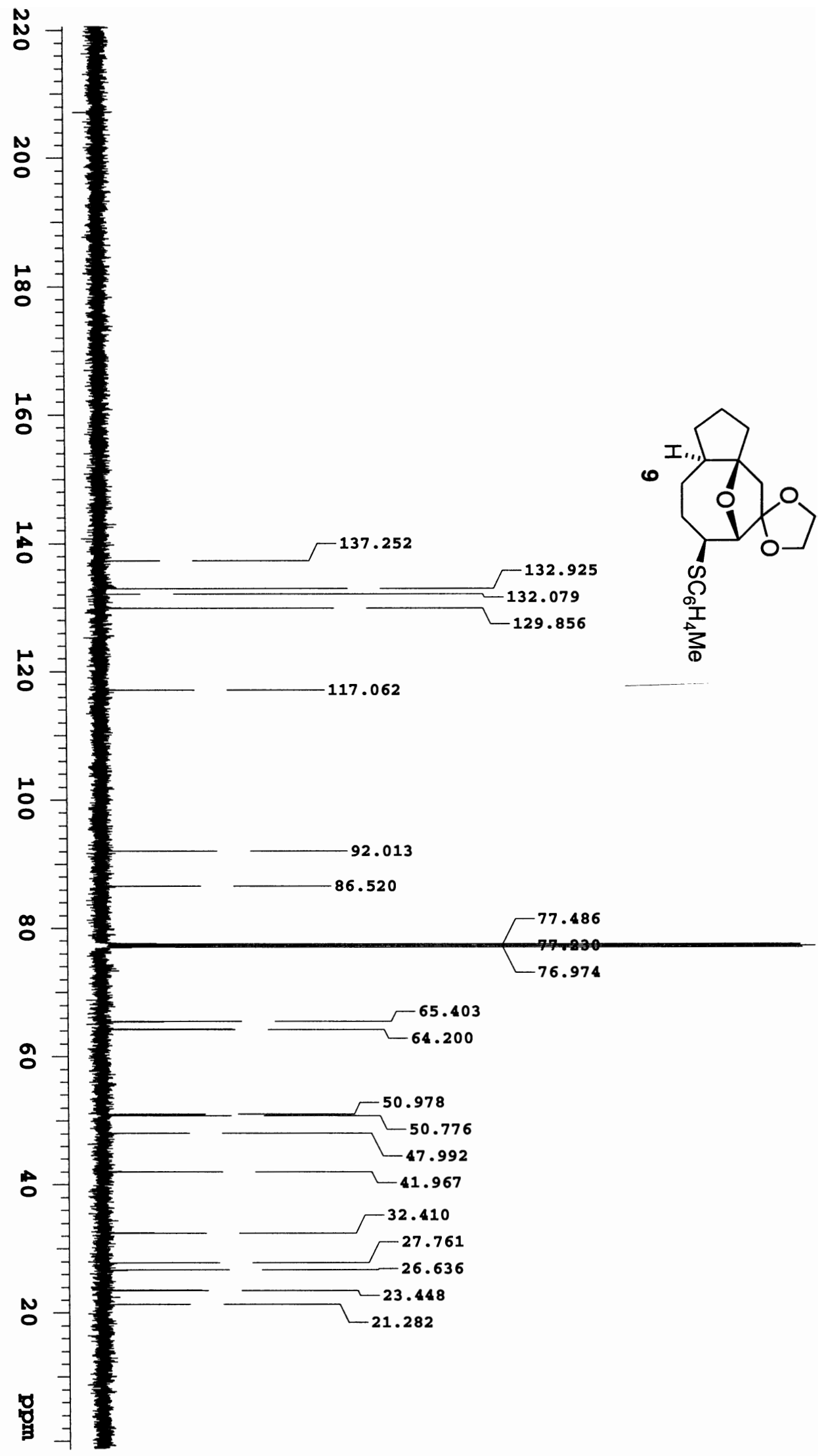




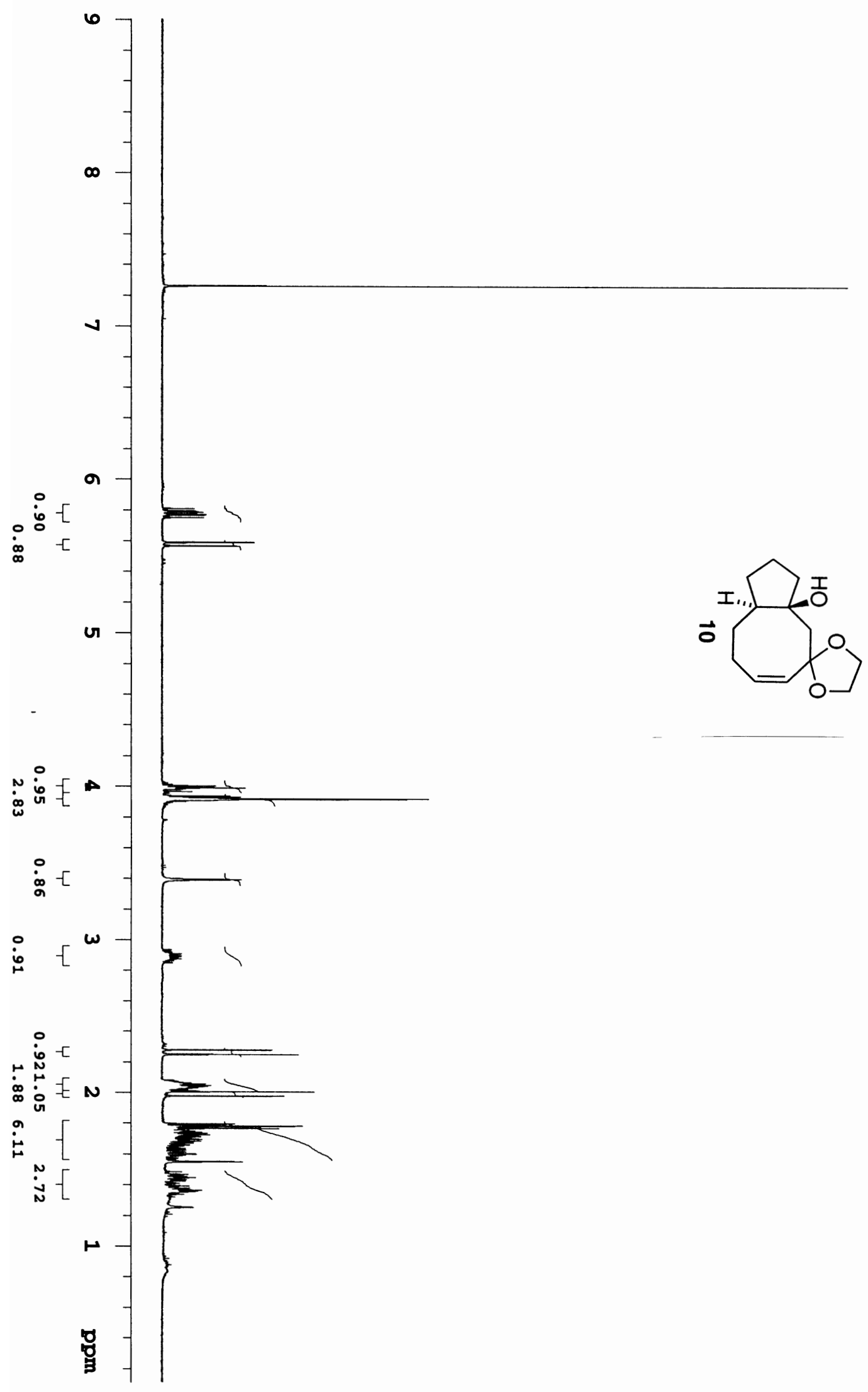




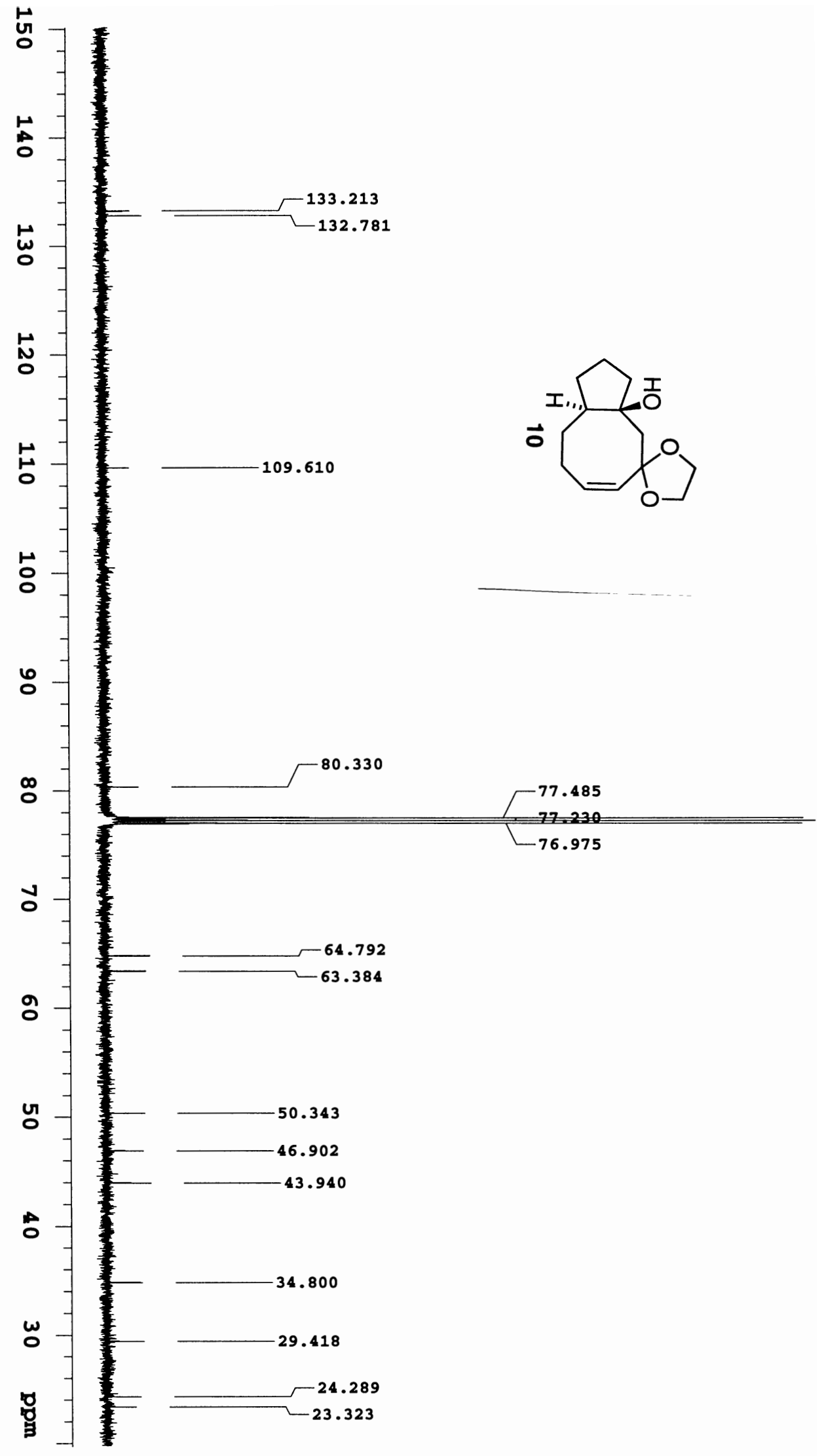

S-23 


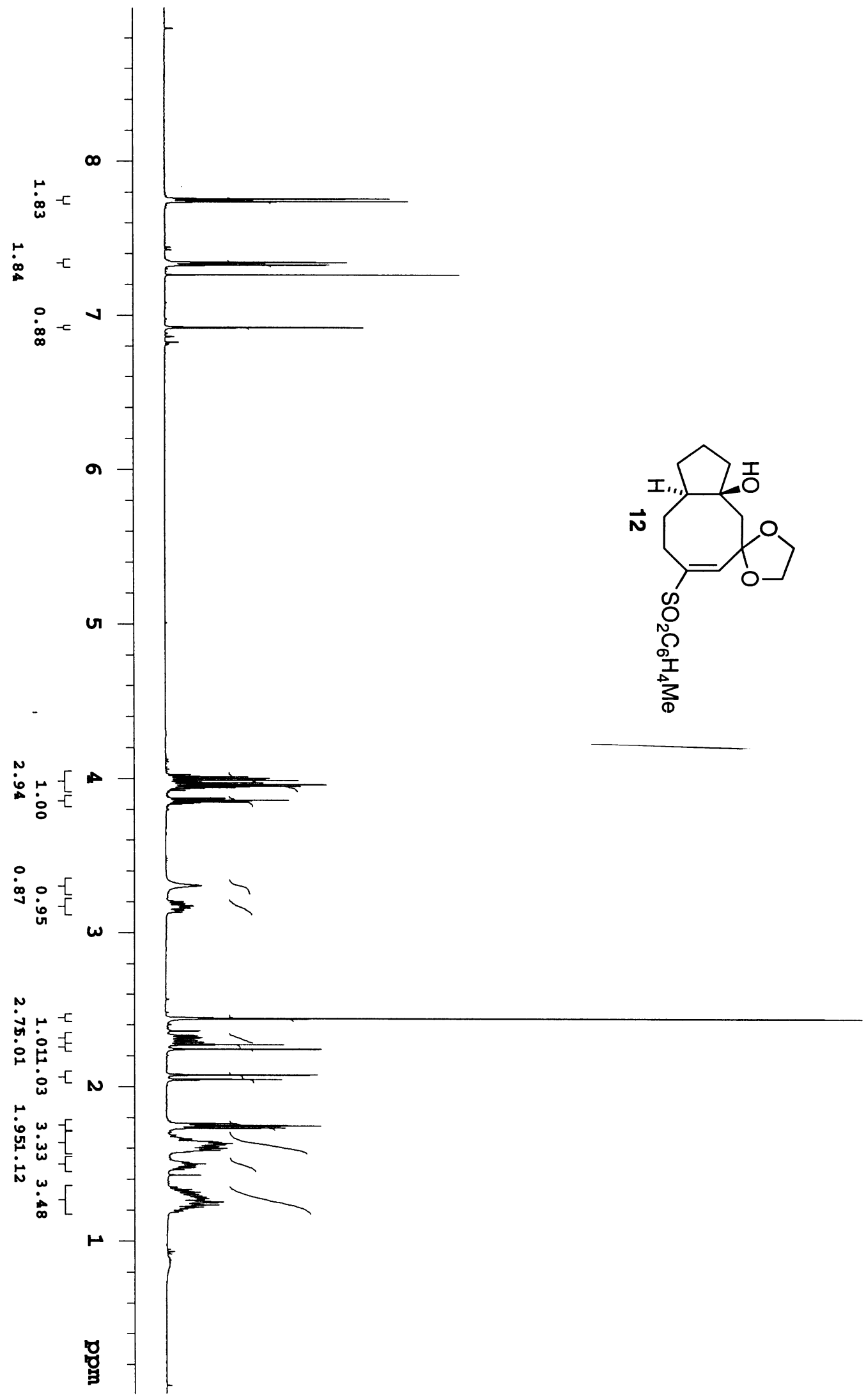




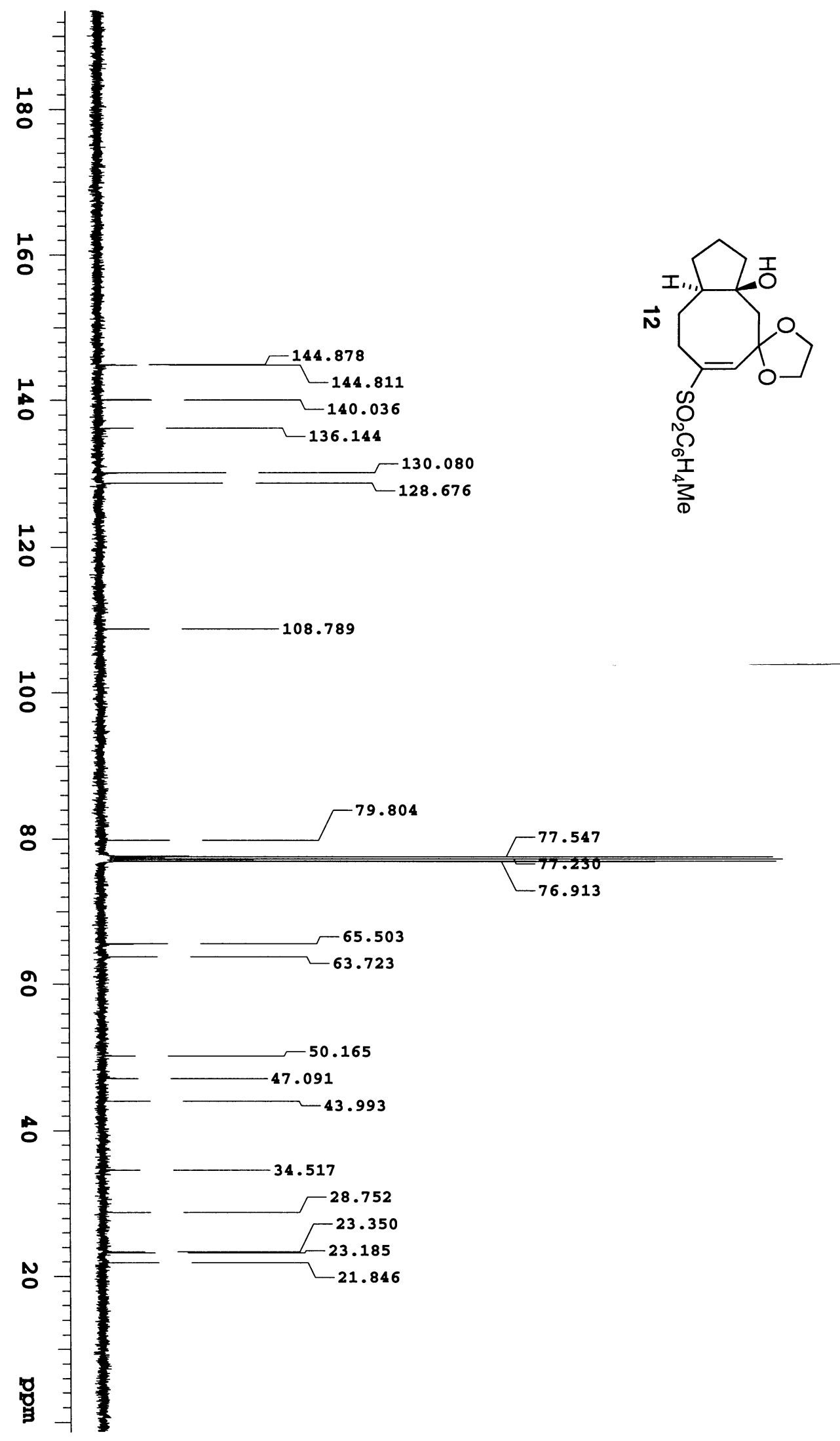

